
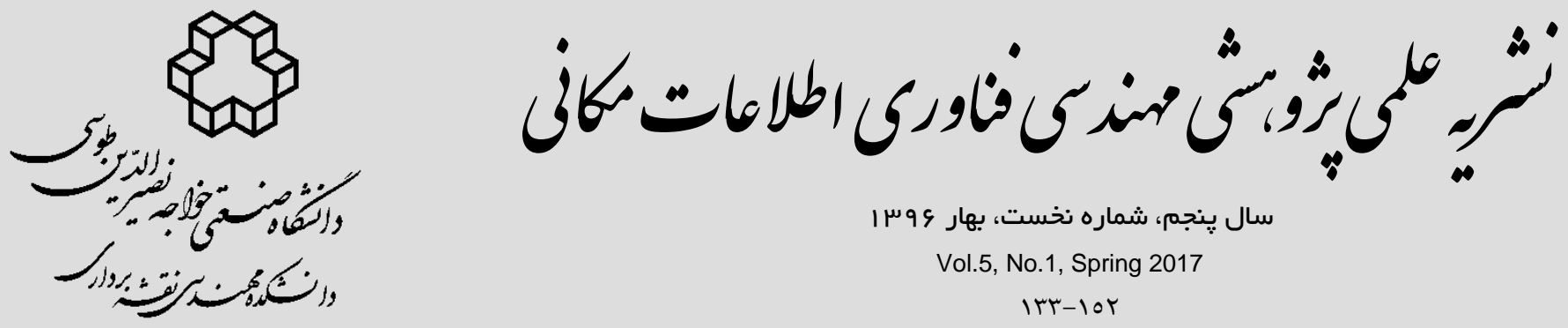

سال ينجمم، شماره نخست، بهار و وسر

Vol.5, No.1, Spring 2017

Irr-10r

ماشينهاى تصادفى بردار يشتيبان، طبقهبندى دستهجمعى بهينه دادهاى با ابعاد بالا

\author{
محسن جعفرى "*.، مهدى آخوندزاده
}

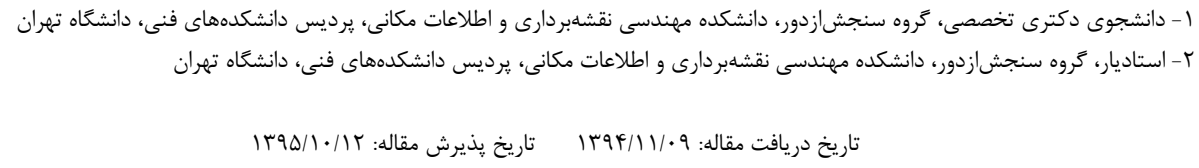

جكيده

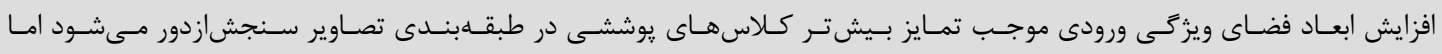

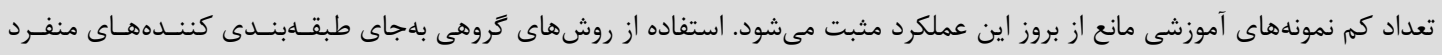

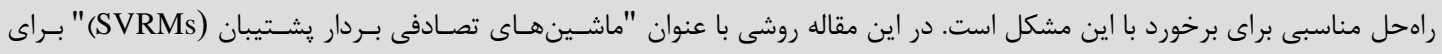

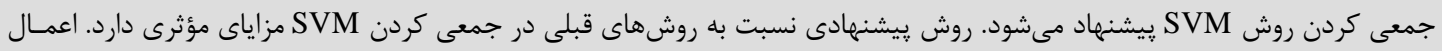

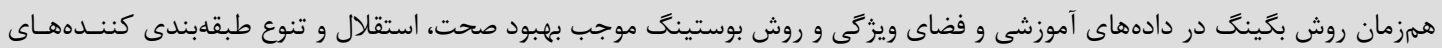

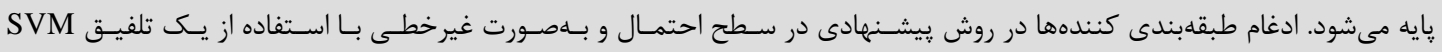

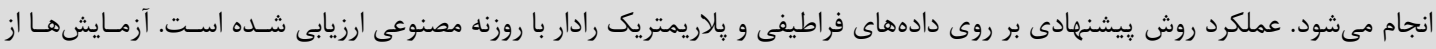

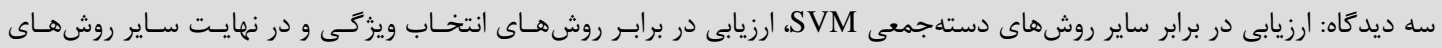

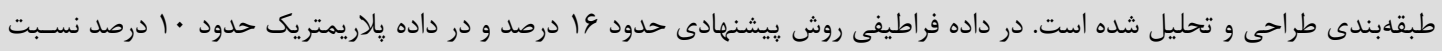

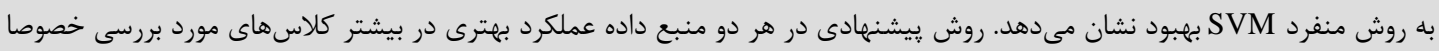

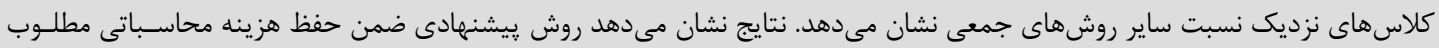

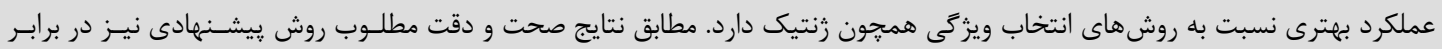

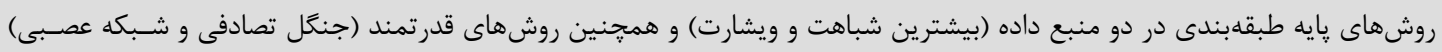
تصديق مىشود. كليدوازهها: ماشين بردار رشتيبان، روشهاى دستهجمعى، فضاى ويزگگى، خود راهانداز تصادفى، تلفيق 
به خاطر افزايش تمايز بين كـلاسهـا اسـت امـا از ايـن

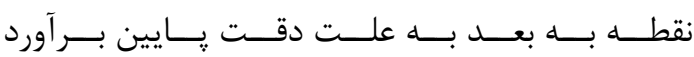
بارامترهاى آمارى، دقت طبقـهـبنـدى كـاهش مسى بابـد. بهعبارتديكر از اين نقطه به بعد آن اثـر مثبـت توســا

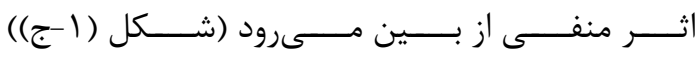

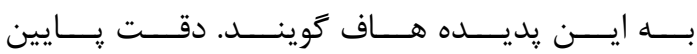

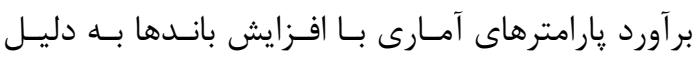

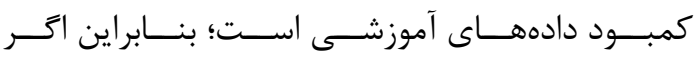

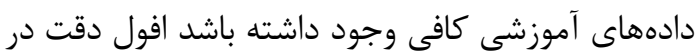

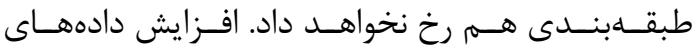

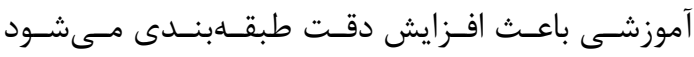

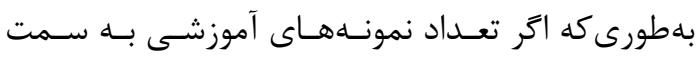

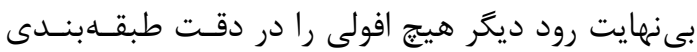

شاهد نخواهيم بود [11].

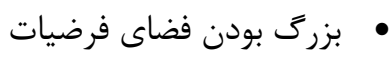

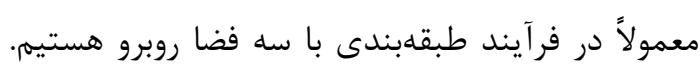
فضاى ويزگى هاى ورودى، فضاى كلاسهاى خروجى و و

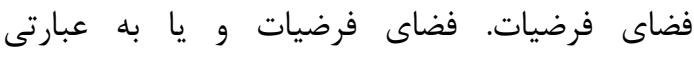

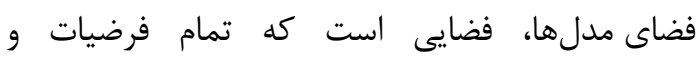

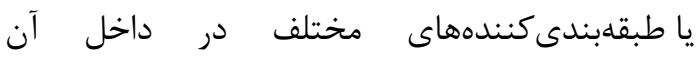
قرار مى گيرند (مانند k همسايه نزديك، شبكه عصبى،

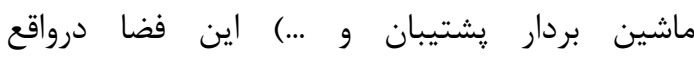
يك فضاى ارتباطى بين فضاى ويزگكىهاى ورودى و و فضاى كلاسهاى خروجى محسوب مىشود (مدلى كه

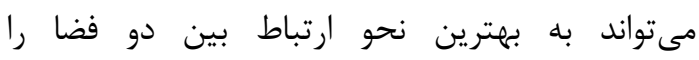

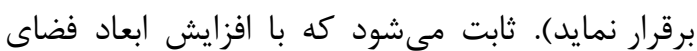

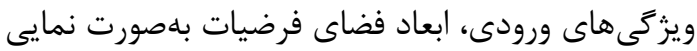

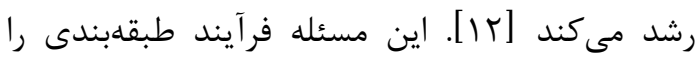
تا حد زيادى غيرقابل اطمينان و نامطمئن مىسازد.
| - 1- مقدمه

با يِيشـفت فنـاورى در سـنجندههـاى سـنجشازدور و

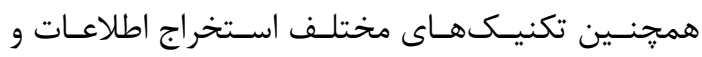

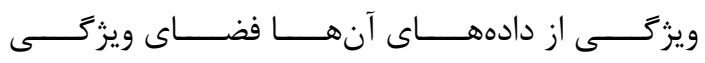

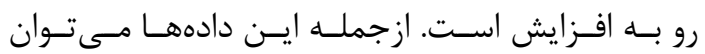

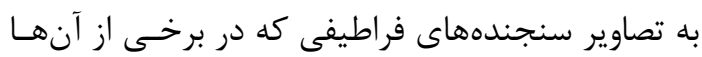

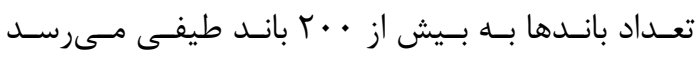

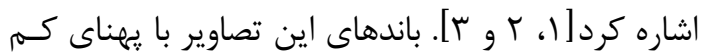

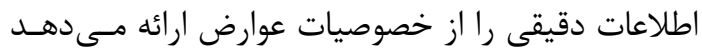

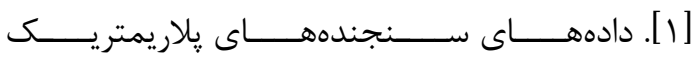

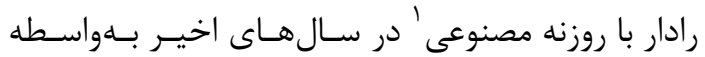

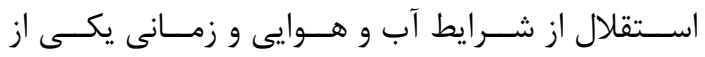

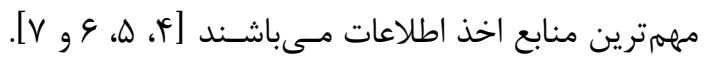

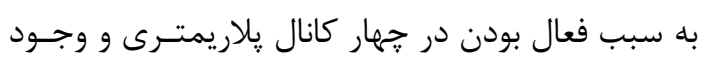
روشهايى مختلفى كه براى استخراج ويزگكى هاى مفيـد

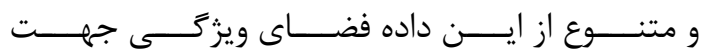

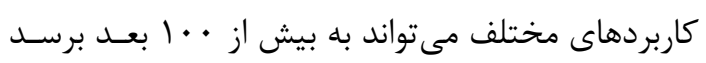
$[9,1]$

معمولاً در طبقهبندى تصاوير با فضاى ويزگى با. ابعاد بالا با دو مشكل روبرو هستيم:

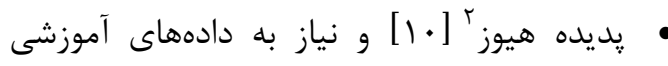
زياد افزايش فضاى ويزگى دو اثر را به دنبال دارد. اولـين اثر

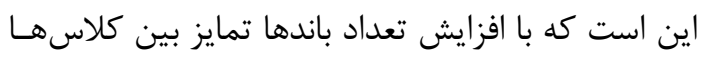

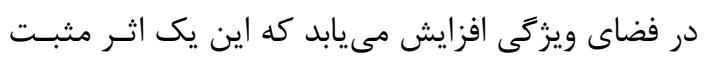

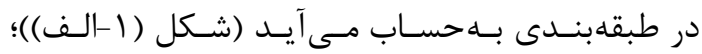

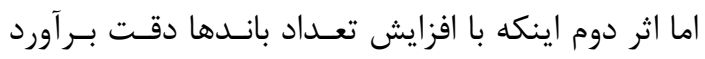

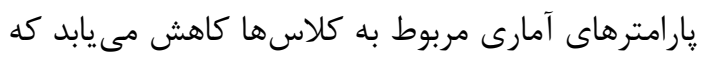

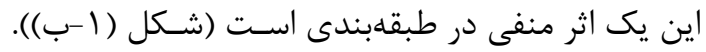

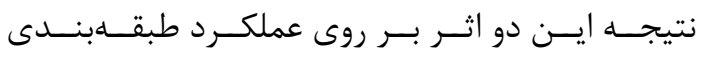

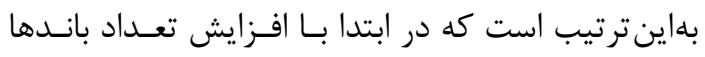
دقت طبقهبندى تا يكى نقطهاى افـزايشيافتـهـ كـهـ ايـنـ

${ }^{1}$ Polarimetric Synthetic Aperture Radar

${ }^{2}$ Hough 


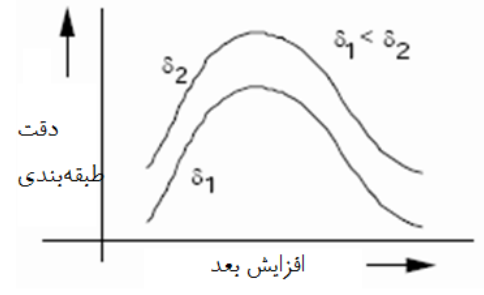

(ج)

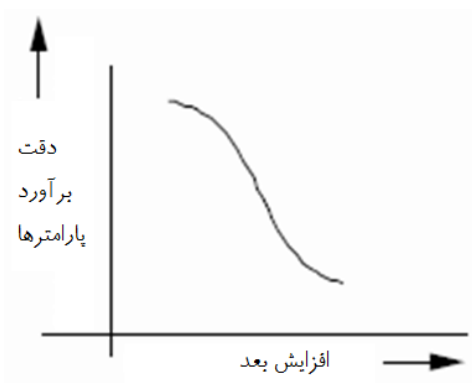

ب)

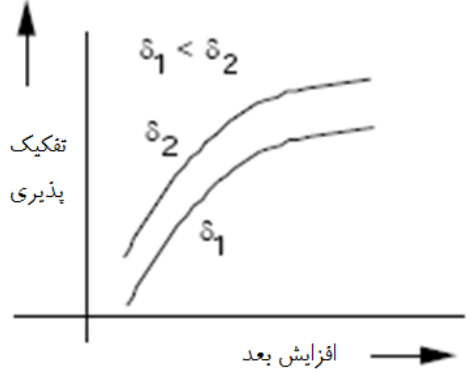

الف)

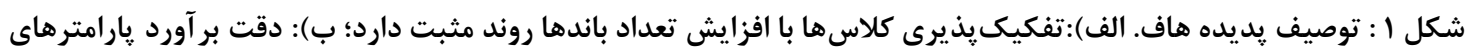

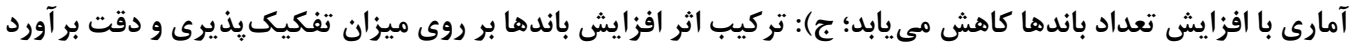

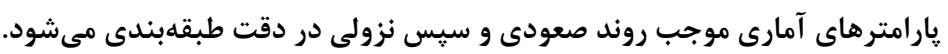

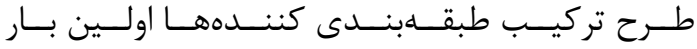

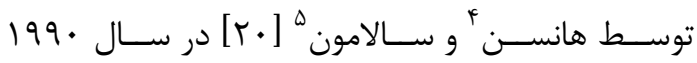
ارائه كرديد. آنها ثابت كردنــ درصـورتى كـهـ هريـك از

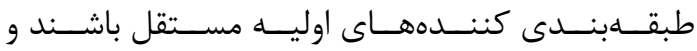

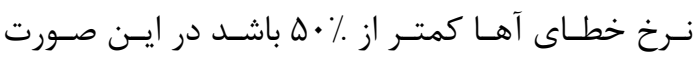

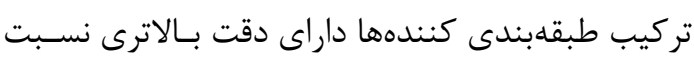

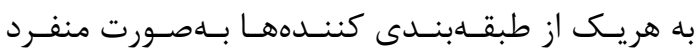

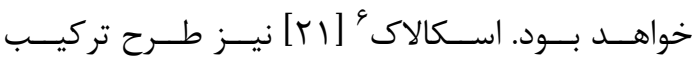

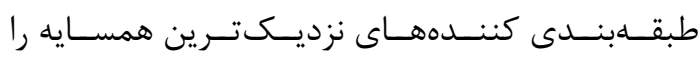

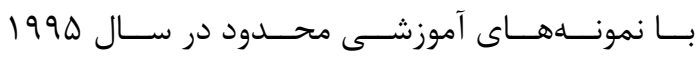

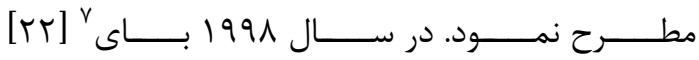

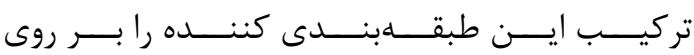

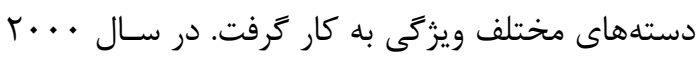

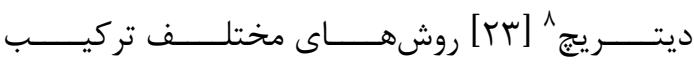
طبقهبندى كنندهها را مطرح و عملكـرد آنهـا را بـاهم مقايسه نمود. دامنه تحقيق بر روى اين موضـوع بسـيار

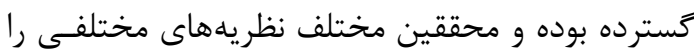

- Hybrid Method - Multiple Experts -Combining Classifiers - Classifier Ensembles

-Classifier Fusion -Mixture of Experts -Decision

Combination -Decision Fusion

${ }^{4}$ Hansen

${ }^{5}$ Salamon

${ }^{6}$ Skalak

${ }^{7}$ Bay

${ }^{8}$ Dietterich
يكى از روشهاى مقابله با مشكلات فوق استفاده از

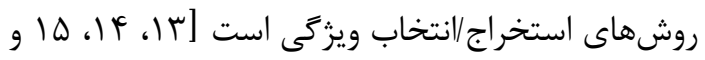

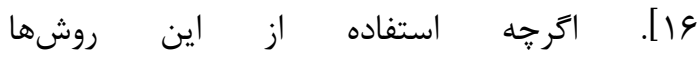

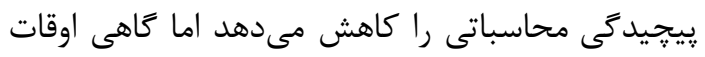

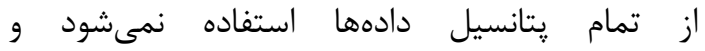
دقت طبقهبندى كاهش مىيابد. راهحل دوم استفاده از

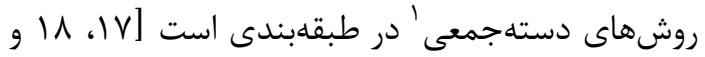

اين روشها بهصورت تركيبى از طبقـهبنـدى كنـــدهــا

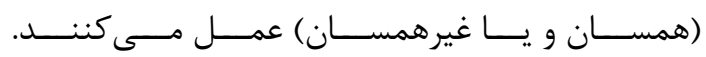
بهطوركلى سه روش براى ايجاد طبقهبندى كنندههـاى

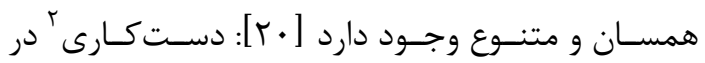

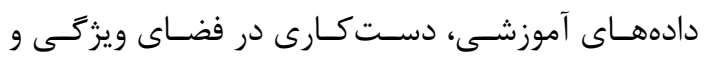

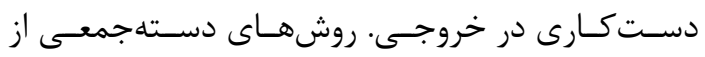

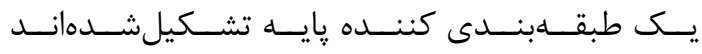
كه وقتى تكثيــر مسىشـوند بايسـد مسـتقل از يكـديخر و تا حد امكان متنوع و سريع باشند.

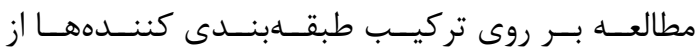

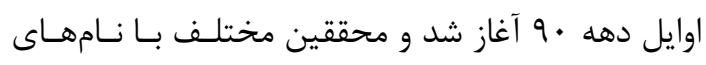

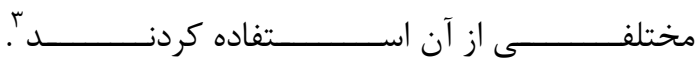

${ }^{1}$ Ensemble Method

${ }^{2}$ Modification

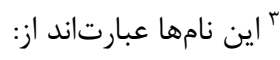




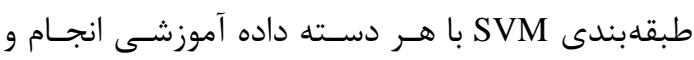

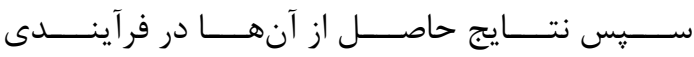

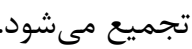
روشهاى ديكرى در جمعى سازى SVM در تحقيقـات

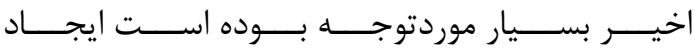

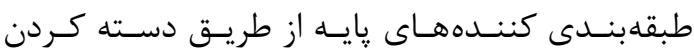

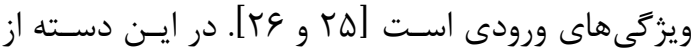
روشها تمايز بين طبقهبندى كنندهها از طريق تنــوع و ودي

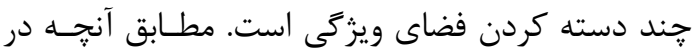
روش بخَينَ وجود دارد با انتخاب همراه بـا جـايكزينى

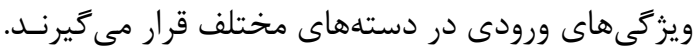

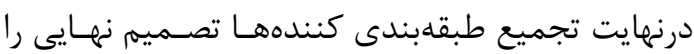

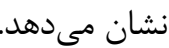

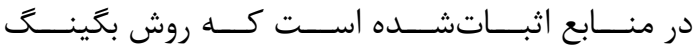

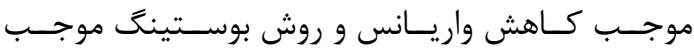

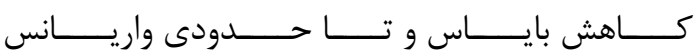

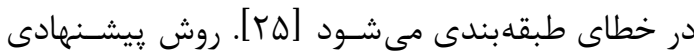
در اين مقاله بهصورت تركيبى از اين دو روش بـ با تأكيـد بر تصادفىتر شدن هر طبقهبندى كننده و ايجـاد تنـوع ائن

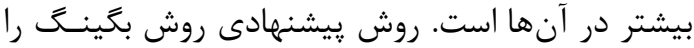

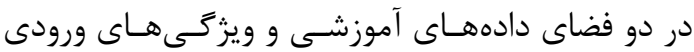
اعمال مى شود و همجنين آموزش هر طبقديندى كنينده

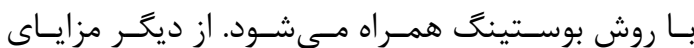

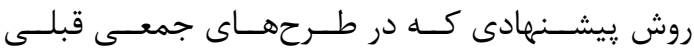

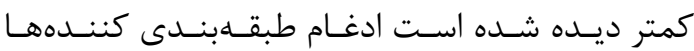

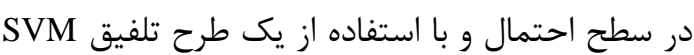

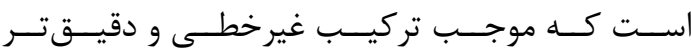
طبقهبندى كنندها مىشود.

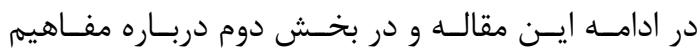

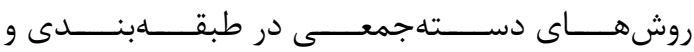

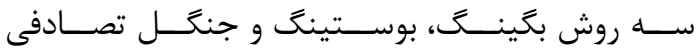

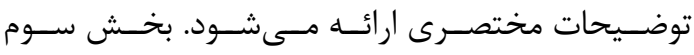

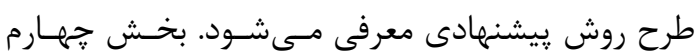

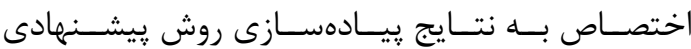
بر روى دادههاى فراطيفى و پِاريمتريك اختصاص دارد.

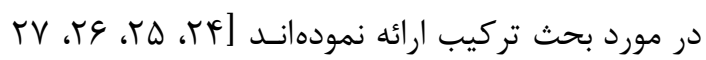
[r人,

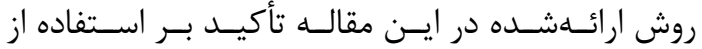

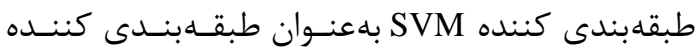

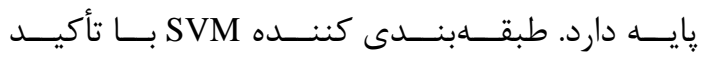

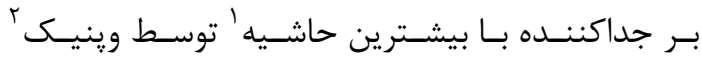

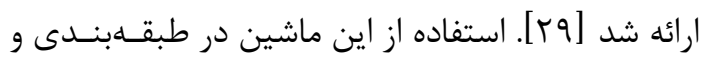

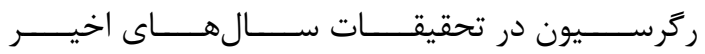

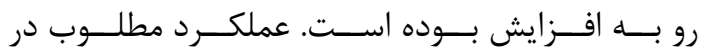
تعداد دادههاى آموزشى كـم ازجملـه مزايـاى SVM و

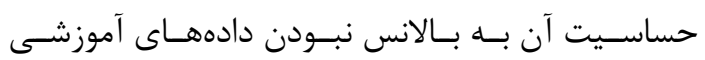
[r.] اسن SVM

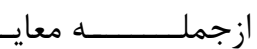

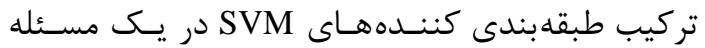
از جمله روشهايى بوده است كه بـراى بهبـون عملكـرد

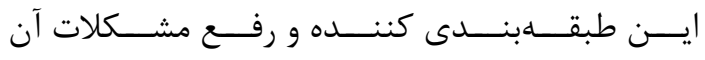

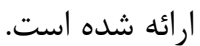
ايده SVM بهصـورت جمعى در [آبـ مطرح كرديـد.

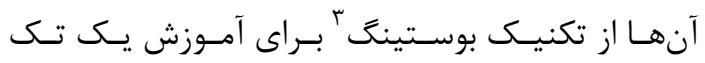

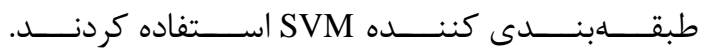

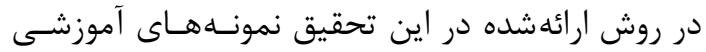

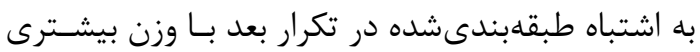

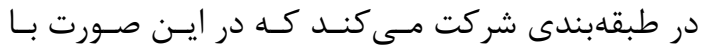

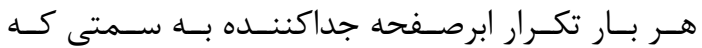
كمترين خطا را دجار شود ميل بيدا مى كند.

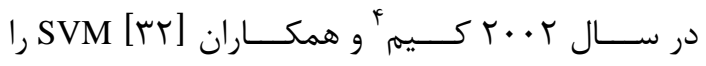
با تكنيك بخينگ ه و ايجاد طبقهبندى كنندهاى متنوع از روى دست كارى دادههاى آموزشى بهصـورت جمعى إنى

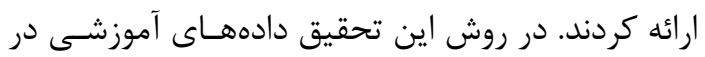

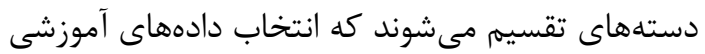

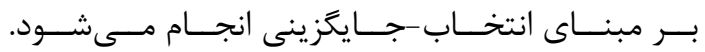

\footnotetext{
${ }^{1}$ Marigin

${ }^{2}$ Vapnik

${ }^{3}$ Boosting

${ }^{4}$ Kim

${ }^{5}$ Bagging
} 


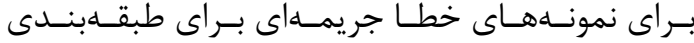

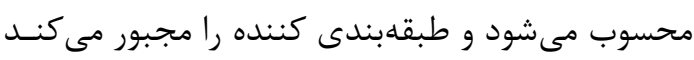
روى موارد خطا تمركز كند [MF].

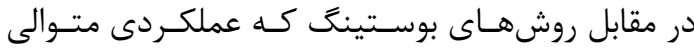

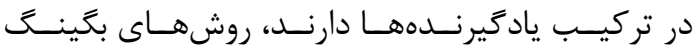

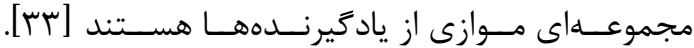

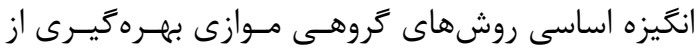

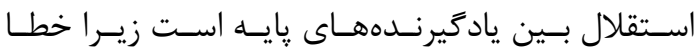

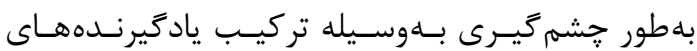

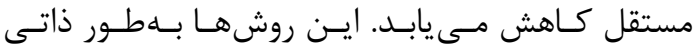

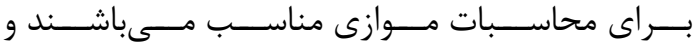

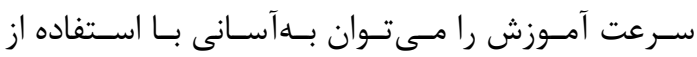

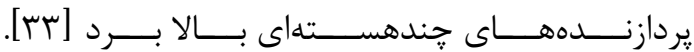

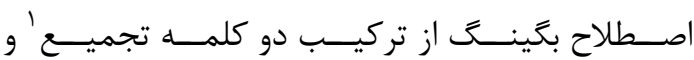

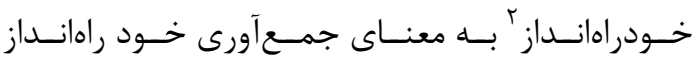
آمده است. مجموعه نمونههاى آموزشى تشـكيلدهنــــــاه

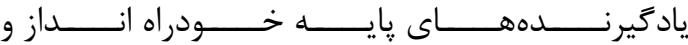

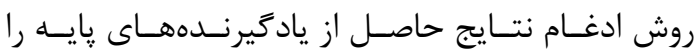

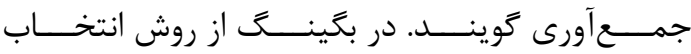

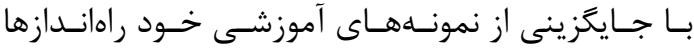

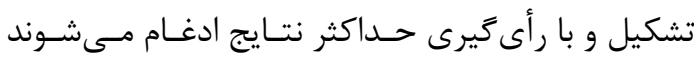

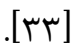

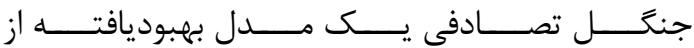

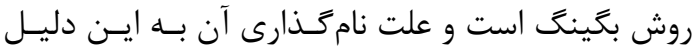

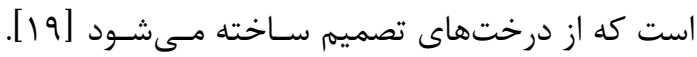

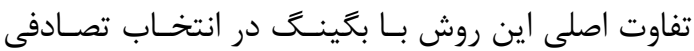

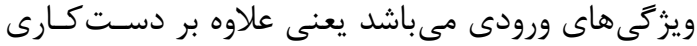

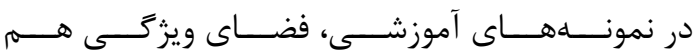

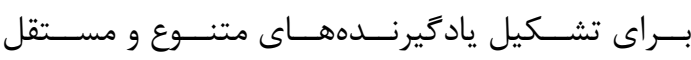
دست كارى مىشود.

\footnotetext{
${ }^{1}$ Aggregating

${ }^{2}$ Bootstarp
}

درنهايت در بخش يــنجم نتيجــــيـرى از ايـن تحقيـق ارائه خواهد شد. - انه

\section{ץ- روش هاى دستهجمعى در طبقهبندى}

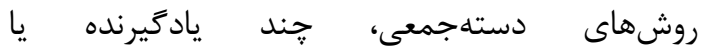

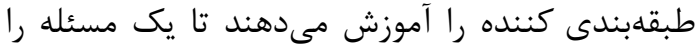
حل كنند. برخلاف رويكردهاى يادَيرى معمولى كه تلاش بر ساخت يك يادكيرنده از دادههاى آموزشى ئى دارند، روشهاى دستهجمعى مجموعهاى از يادكيرندهائ

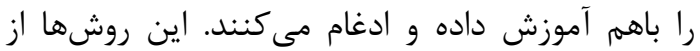

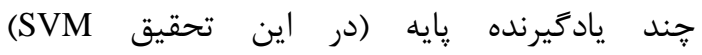
تشكيلشدهاند كه از دادههاى آموزشى ساخته مىشود. اين يادَيرندهها بايد تا حد امكان صحيح و گَوناكون

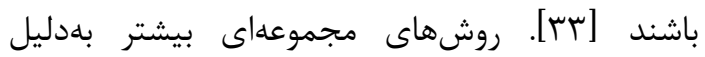
توانيى كه در تقويت يادگيرندههاى ضعيف دارند،

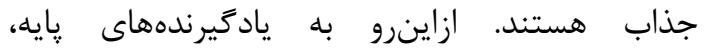

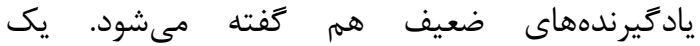
تحقيق تجربى نشان داده كه بِيشبينىهاى ساختهشده

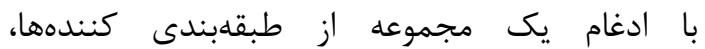
اغلب صحيحتر از پيشبينىهايى هستند كه بلهوسيله

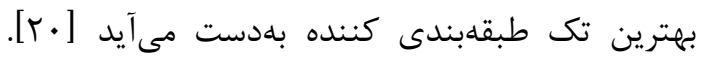
اغلب هزينه محاسباتى ساخت يك مجموعه قوى از ساخت يك يادكيرنده قوى كمتر است [سب].

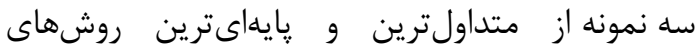
دستهجمعى بوستينَ، بخَينَ و جنَّل تصادفى است.

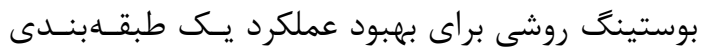
كننده ضعيف است. اساس روش بوستينَ اين است كه

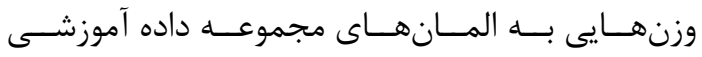

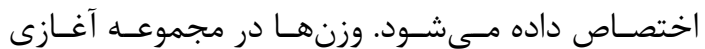

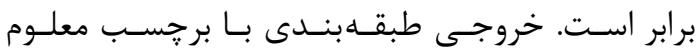

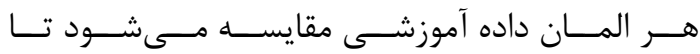

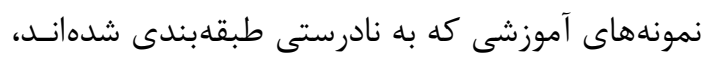

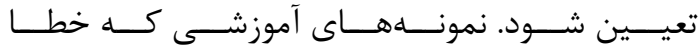

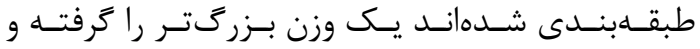
طبقهبندى كننده دوباره اجرا مى شود. ايسن وزن بيشـتر 


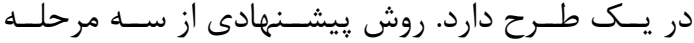

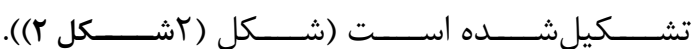

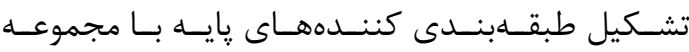

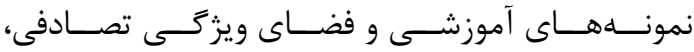
آموزش طبقهبندى كنندهها بهصورت متوالى و درنهايت

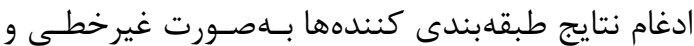
در سطح احتمال و به روش SVM.

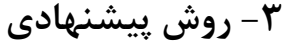

همان طــور كـهـ يـيشـتـر نيـز اشـاره شـد هـدف اصـلى

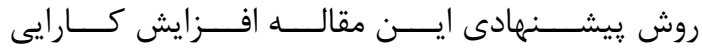

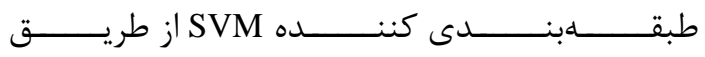
دسـتهجمعـى كــردن آن اسـت. روش گروهــىسـازى ارائــشــده در ايــن تحقيـق از ســه روش ذكرشــــه در

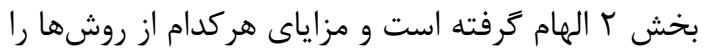

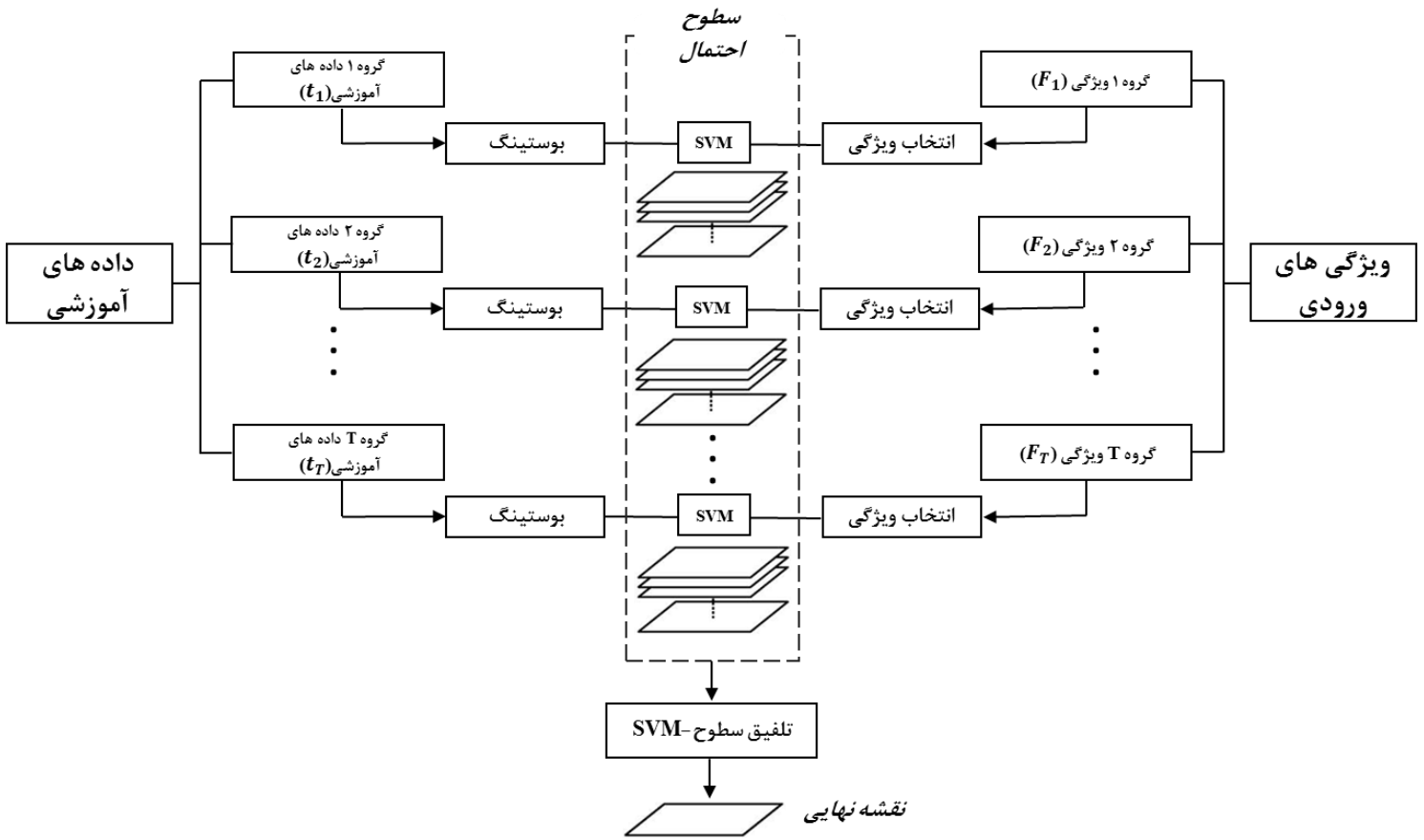

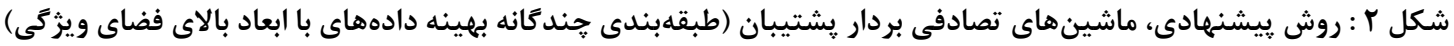

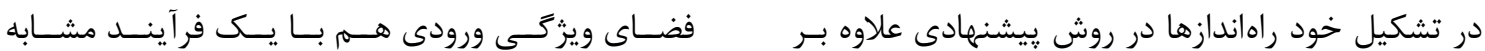

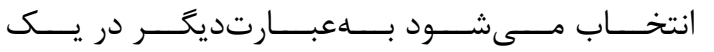

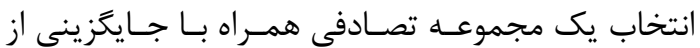

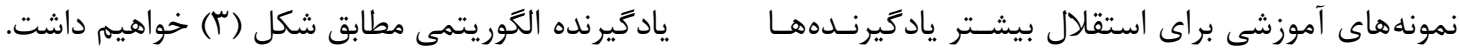

\section{Algorithm. Bootstrap}

INPUT: $F, U, K=$ size of bootstrap samples, $R=$ size of bootstrap features, $T=$ number of bootstraps

OUTPUTS: $U_{t}, F_{t}$

for $t=1$ to $T d o$

Draw a bootstrap sample $U_{t}$ of size $K$ in $U$.

Draw a bootstrap feature $F_{t}$ of size $R$ in $F$.

end for

شكل ץ : الكوريتم خودراهانداز يِيشنهادى 


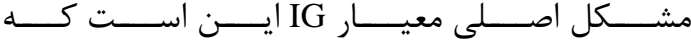

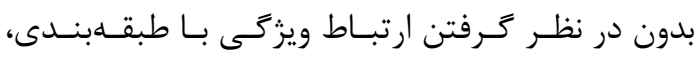

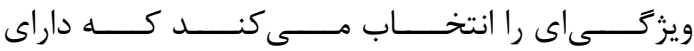

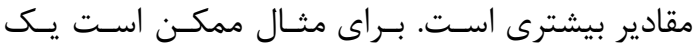
ويزگى مثل "id" وجود داشته باشد كه براى هـر نمونسه

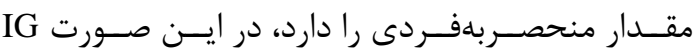
اين ويزگى را بهعنوان بهترين ويزگى براى تقسـيم داده

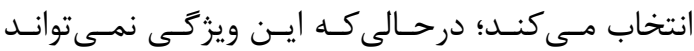
تعميم داده شود و براى ييشبينى مناسب نيست [بسابـ

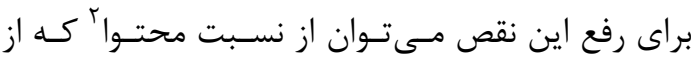
رابطه (Г) بهدست مى آيد استفاده كرد.

رابطه (广) رابطه (i)

$\mathrm{P}\left(\mathrm{D} ; \mathrm{D}_{1} ; \ldots ; \mathrm{D}_{\mathrm{k}}\right)=$

$\mathrm{G}\left(\mathrm{D} ; \mathrm{D}_{1} ; \ldots ; \mathrm{D}_{\mathrm{k}}\right) \cdot\left(\sum_{\mathrm{i}=1}^{\mathrm{k}} \frac{\left|\mathrm{D}_{\mathrm{k}}\right|}{|\mathrm{D}|} \log \frac{\left|\mathrm{D}_{\mathrm{k}}\right|}{|\mathrm{D}|}\right)^{-1}$

كام مههم ديكر در روش پيشنههادى استفاده از روش

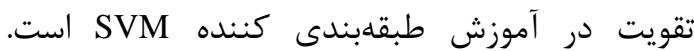

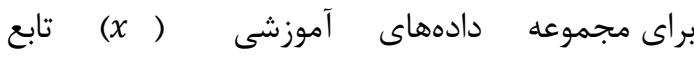

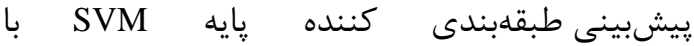
در نظر ترفتن تابع كرنل K عبارت است از (رابطه (f))

:[rद]

$\operatorname{sign}\left(f(x)=\sum_{i=1}^{n} y_{i} \alpha_{i} K\left(x, x_{i}\right)+b\right) \quad$ (أبط در اين رابطه b باياس است و ضرايب بهينه با بيشينه كردن معادله لاكرانز مطابق رابطه (a)

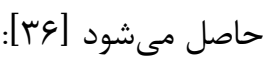

با معلوم بودن m نمونهى آموزشى، احتمال اينكه

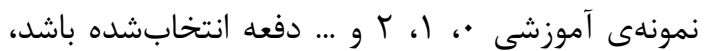

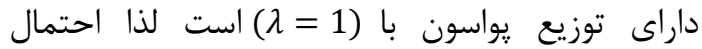
اينكه نمونه iام اتفاق بيفتد

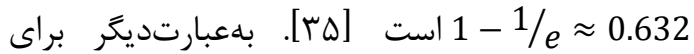
هر يادگيرنده بايه در حدود /|اعب درصد از نمونههاى آموزشى اوليه در يروسه ي يادكيرى مورد استفاده قرار نمى گيرد. ميزان شايستخى هر يادگيرنده بايه در روش پيشنهادى با استفاده از نمونههاى استفادهنشده در آموزش آن برآورد مىشود.

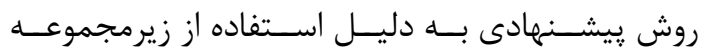

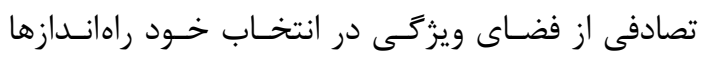
نسبت به روش مرسوم بخَينگ انعطاف بالاترى دارد كـهـ

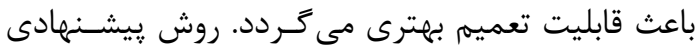

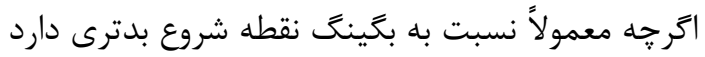

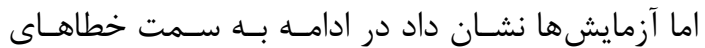

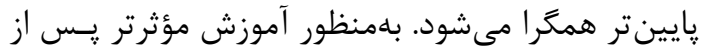

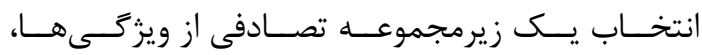

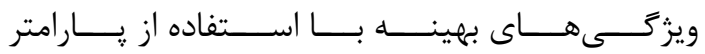
محتواى اطلاعاتى' (IG) وارد طبقهبندى كنــــ SVM

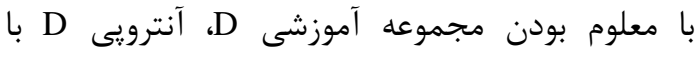
رابطه ( ) محاسبه مى كر دد: رابطه (1)

$\operatorname{Ent}(D)=-\sum_{y \in Y} P(y \mid D) \log P(y \mid D)$

اكر مجموعه آموزشى D به زيرمجموعههاى تقسيم كردد، ممكن است آنترويى كاهش يابد و و مقدار كاهش، همان (IG) است، يعنى: (T) رابطه $G\left(D ; D_{1}, \ldots, D_{k}\right)=$ $\operatorname{Ent}(D)-\sum_{i=1}^{k} \frac{\left|D_{k}\right|}{|D|} \operatorname{Ent}\left(D_{k}\right)$

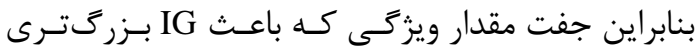
بشـود بــهنــوان معيـار مناسـب انتخــاب مسى شعـود.

${ }^{1}$ Information Gain 
$\mathrm{L}_{\mathrm{P}}=\frac{\|\vec{\omega}\|}{2}+\mathrm{C}+\sum_{\left\{\mathrm{i} \mid \mathrm{y}_{\mathrm{i}}=+1\right\}}^{\mathrm{n}_{+}} \xi_{\mathrm{i}}^{2}+\mathrm{C}-\sum_{\left\{\mathrm{i} \mid \mathrm{y}_{\mathrm{i}}=+1\right\}}^{\mathrm{n}_{-}} \xi_{\mathrm{i}}^{2}-\sum_{\mathrm{i}=1}^{\mathrm{n}} \alpha_{\mathrm{i}}\left[\mathrm{y}_{\mathrm{i}}\left(\omega \cdot \mathrm{x}_{\mathrm{i}}+\mathrm{b}\right)-1+\xi_{\mathrm{i}}\right]-\sum_{\mathrm{i}=1}^{\mathrm{n}} \mu_{\mathrm{i}} \xi_{\mathrm{i}} \quad$ (b) رابطه

طرح ادغام در روش يِشنهادى در سطح احتمال حاصل

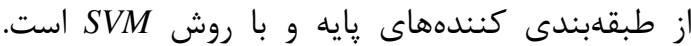

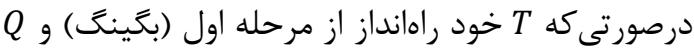

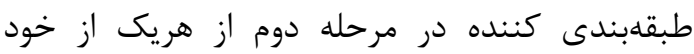

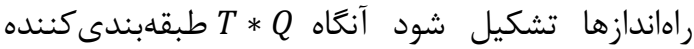
يايه سطوح احتمال را توليد ميكنند كه در - SVM بdusion

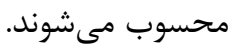
در تمام طبقهبندهاى קايه (SVM) در اين مقاله از

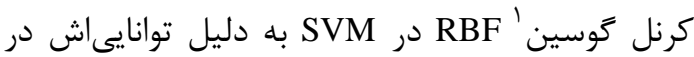
كنترل دادهها با ابعاد بالا استفادهشده است.

$$
\mathrm{K}\left(x_{i}, x_{j}\right)=\exp \left(-\frac{\left\|x_{i}-x_{j}\right\|^{2}}{2 \sigma^{2}}\right) \quad \text { (9) }
$$
كه در اين كرنل م واريانس در امتداد محورهاى

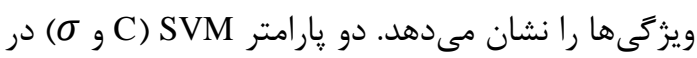
اين مقاله به كمك روش جستجوى شبكهاى در هر تره

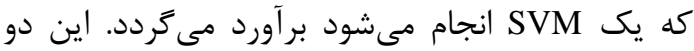

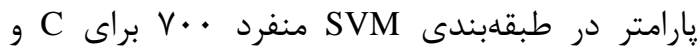
ا • • براى $\sigma$ با روش جستجوى شبكهاى محاسبهشده است. اين دو پارامتر در تمام طبقهبندى كنندههاى يايه دوباره محاسبه مىشود.

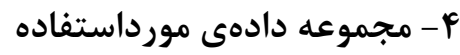
بهمنظور ارزيابى روش زيشنههادى دو مجموعه داده با ابعاد فضاى ويزگى بالا انتخاب شد. داده هوابرد بادئن

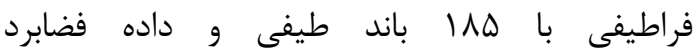
بلاريمتريك رادارى كه با استخراج ويزگى هاى مختلف

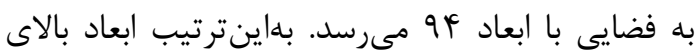

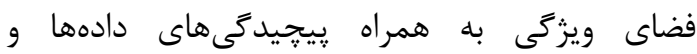
نمونههاى آموزشى كنترلشده جالشهاى مختلف روش بِيشنهادى را بررسى كند.
در رابطه (a) نامساوىها مطابق رابطه (9 و V)

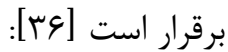
رابطه (9) $C_{+} \geq \alpha_{i} \geq 0, C_{-} \geq \alpha_{i} \geq 0, \frac{C_{+}}{C_{-}}=\frac{n_{+}}{n_{-}}$and $\mu_{i} \geq 0$ $\xi_{i}^{*}=\xi_{i} /\|\beta\|$

رابطه (V)

ا ميزان خطاى هر نمونه آموزشى در اطراف حاشيه

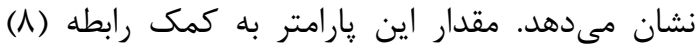
قابل برآورد است [عץ]. رابطه (ᄉ) $\xi_{i}=\max \left(0,1-y_{i}\left(\sum_{i=1}^{n} y_{i} \alpha_{i} K\left(x, x_{i}\right)+b\right)\right)$ كام بعدى در آموزش SVM تغيير وزن

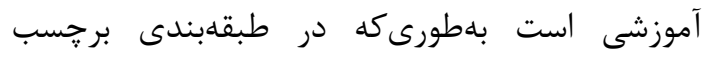
نمونههاى $x_{i}$ اصلاح صورت كيرد. روند اصلاح حاشيه در روش ييشنهادى در شكل(أ) نشان دادهشده است.

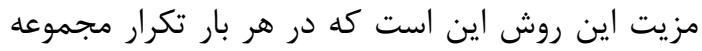

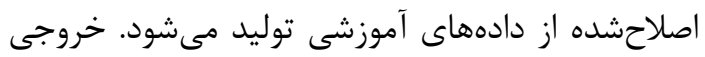
هر بار تكرار طبقهبندى كنندههاى درنهايت مى تواند در درائ يك فرآيند ادغام برجسب نهايى نمونهها را تعيين كند

[بع]

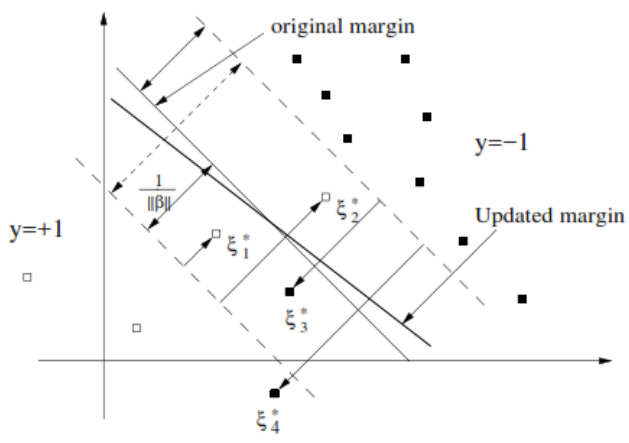

شكل F : روند اصلاح حاشيه در آموزش SVM در روش

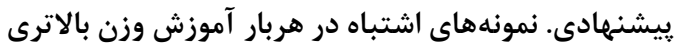

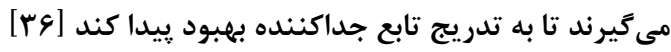

\footnotetext{
${ }^{1}$ Gaussian
} 


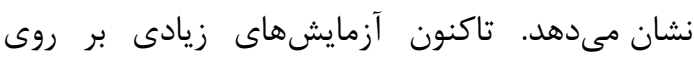
اين تصوير انجامشده است كه درنتيجه اطلاعات مفيدى

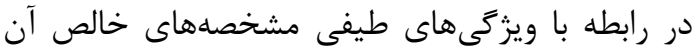

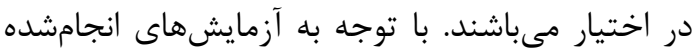

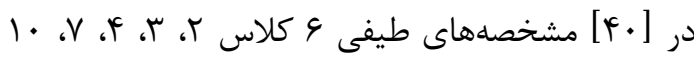
و rا ازلحاظ سنجههاى اندازهكيرى تشابه طيفى به يكديخر بسيار شبيه مىباشند. درنتيجه تشخيص تمايز

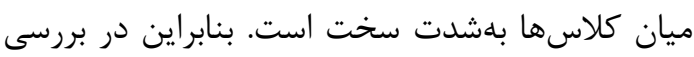

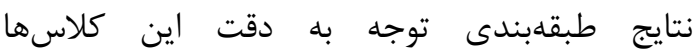
بسيار مناسب خواهد بود.
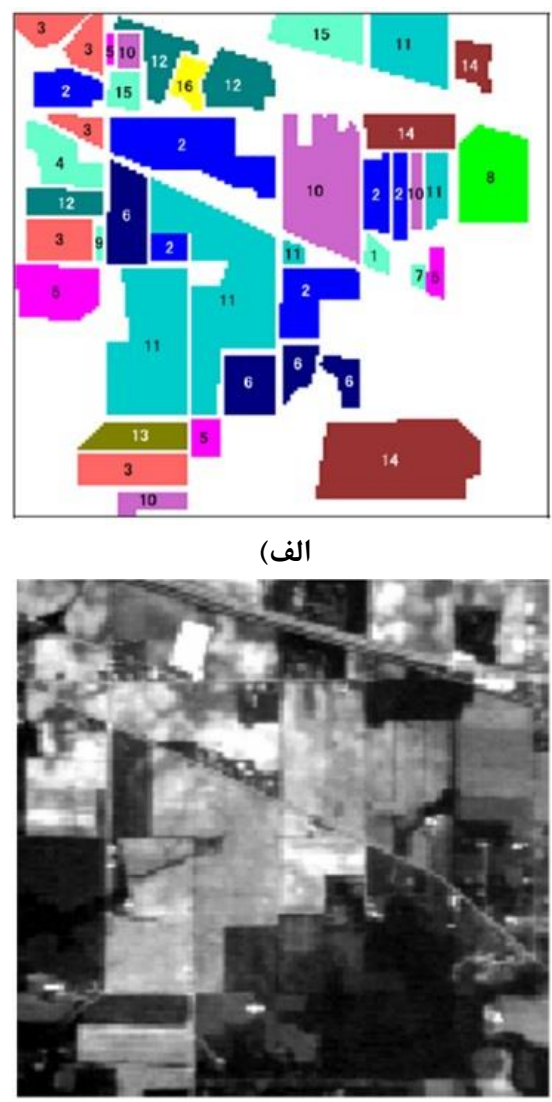

(ب)

شكل ه : منطقهى موردمطالعه اول الف): نقشهى حقيقى

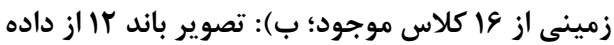

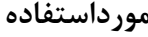

\section{F- ا- - مجموعه داده فراطيفى}

منطقهى جنگلى/ كشاورزى در شمال غرب ايالت

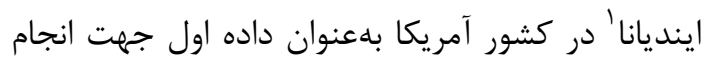

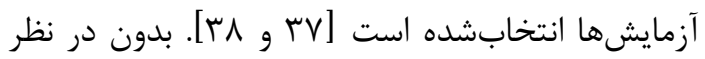

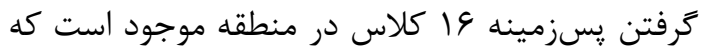

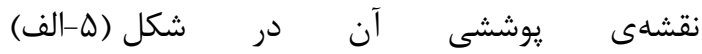

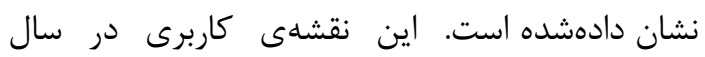
ب991 او با كار زمينى تهيهشده است. حدود سب در درصد منطقه يوشش جنكلى و 99 درصد آن آنوشش

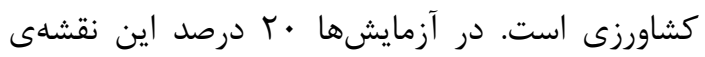

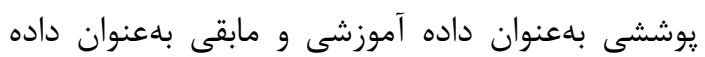
آزمايشى استفادهده است. نام كلاسها و شمارهى

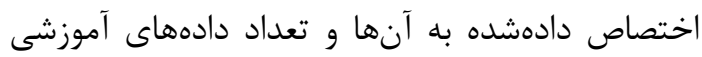
در هر كلاس در جدول (1) آمده است. معتبر بودن دادهاى حقيقى و داده ابرطيفى موجود از منطقه از دلايل مهم استفاده از اين منطقه براى انجام آنمائي آزمايشها است.

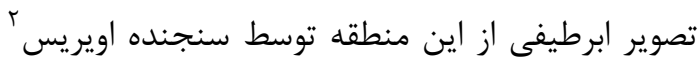

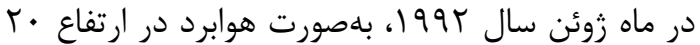
كيلومترى تصويربردارى شده است. تصوير اخذشده

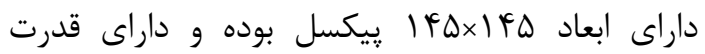
تفكيك مكانى ·r متر و قدرت تفكيك راديومتريكى

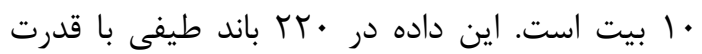

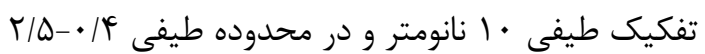

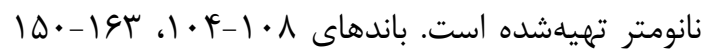

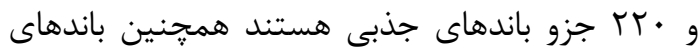

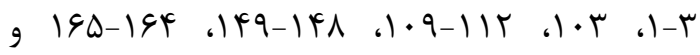

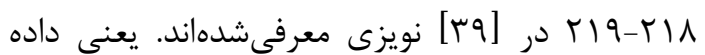
مورد استفاده در مجموع شامل • ب باند جذبى آب و 10

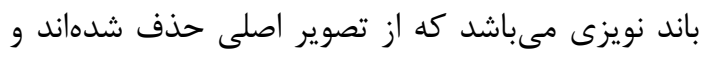

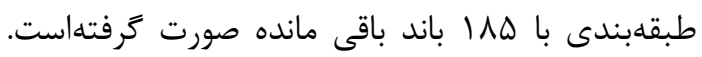

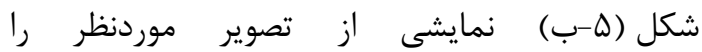

\footnotetext{
${ }^{1}$ Indiana

${ }^{2}$ AVIRIS
} 
جدول ا : تعداد دادههاى آموزشى كلاسهاى مورد بررسى در داده فراطيفى

\begin{tabular}{|c|c|c|c|c|c|}
\hline شماره & نام كلاس & " آموزشى & شلاس & نام كلاس & $\begin{array}{c}\text { آموزشى } \\
\text { آموزى }\end{array}$ \\
\hline 1 & يونجه & $\Delta f$ & 9 & جو دوسر & $r$. \\
\hline$r$ & ذرت 1 & IfTr & 1 . & سويا 1 & $99 \wedge$ \\
\hline r & ذرت & NHF & 11 & سويا r & TYGA \\
\hline f & ذرت & trut & ir & سويا r & qIf \\
\hline$\Delta$ & جمن /مرتع & FqV & r & حَندم & rIT \\
\hline 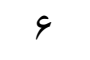 & جمن /درخت & VFV & if & جنگل & IrFq \\
\hline V & جمن /مرتع -درو & rG & 10 & ساختمان سبز & ऍ^. \\
\hline$\Lambda$ & يونجه خشك & $4 \wedge 9$ & 19 & برج سنگى و فولادى & 90 \\
\hline
\end{tabular}

در مورد روشهاى تجزيه ناهمدوس ابتـدا كـاهش نـويز

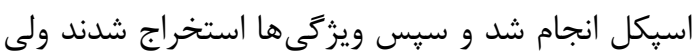

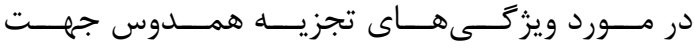

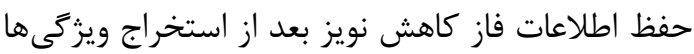
انجام شد. درمجموع فضاى ويزگ

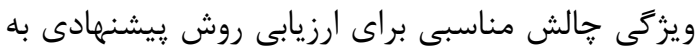

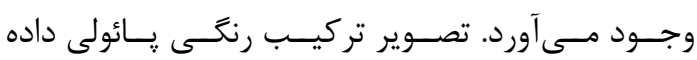

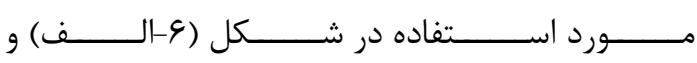

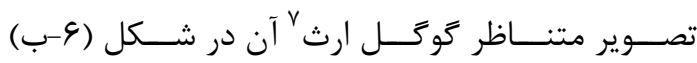

نشان دادهده است.

جدول r : دادههاى آموزشى و آزمايشى مجموعه داده اول

\begin{tabular}{|c|c|c|c|}
\hline نماد كلاس & ماهيت & \# آموزشى & \# آزمايشى \\
\hline Ro & جاده & $11 \mathrm{~V}$ & $1 \Delta T$ \\
\hline $\mathrm{Bu}$ & ساختمان & rqq & $\Delta T \Lambda$ \\
\hline $\operatorname{Tr}$ & درخت & rV. & FFY \\
\hline $\mathrm{Wa}$ & آب & ry. & $\Delta \cdot r$ \\
\hline GV & يوشش گياهى & $r \cdot q$ & $\Delta r V$ \\
\hline \multicolumn{2}{|c|}{ مجموع } & $10 \cdot r$ & rlar \\
\hline
\end{tabular}

${ }^{7}$ Google Earth
F - F - مجموعه داده يلاريمتريك

تصوير يلاريمتريك از منطقهى شهرى سانفرانسيسـكو'

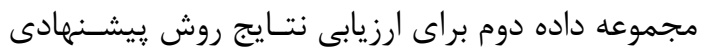
در فضايى متمايز از تصاوير فراطيفى است. ايسن تصـوير

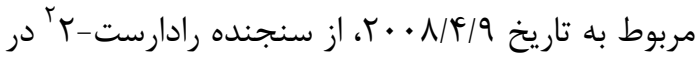

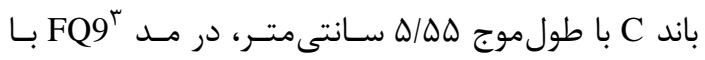

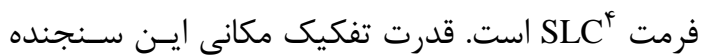

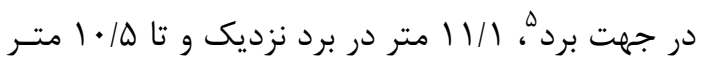
در برد دور است. كلاسهاى موردنظر و تعداد دادههـاى

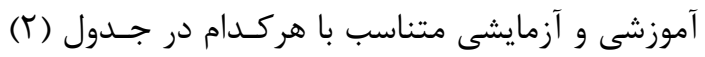

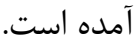
مراحل يِيش يردازش داده تمـام يلاريمتريـك ســنجنده

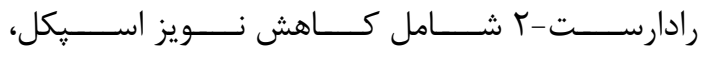
زمين مرجع كردن تصوير و درنهايت استخراج يارامترها (ويزگى هاى) يلاريمتريك است. در اين تحقيق از فيلتـر باكس كار ‘' با ابعـاد 5 × 5 بـراى كـاهش نــويز اسـيكل

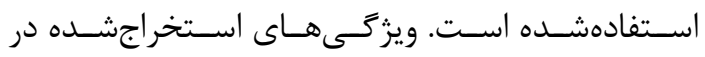

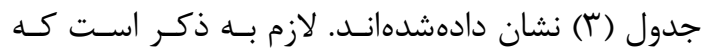

\footnotetext{
${ }^{1}$ San Francisco

${ }^{2}$ Radarsat-2

${ }^{3}$ Fine quad

${ }^{4}$ Single Look Complex

${ }^{5}$ Range

${ }^{6}$ Box-car
} 


\begin{tabular}{|c|c|c|}
\hline ويزگى & توصيف و نماد & تعداد \\
\hline \multirow{3}{*}{ ويزگ هاى اصلى } & ماتريس يراكنش' 'S] & $r$ \\
\hline & ماتريس همدوسى ' [T] & $\wedge$ \\
\hline & ماتريس كواريانس " [C] & 9 \\
\hline \multirow{10}{*}{ ويزگكىهاى تجزيه } & تجزيه كروكاتر" & $r$ \\
\hline & هوينن & 9 \\
\hline & بارنز & 9 \\
\hline & كلود" & 9 \\
\hline & هلم؟ & 9 \\
\hline & ون زيلج & $r$ \\
\hline & فريمن -دردن '1 & r \\
\hline & ياماگوجى & f \\
\hline & توزى & r \\
\hline & كلود-ياتير rا' & 19 \\
\hline \multirow{3}{*}{ تفكيك كنندههاى SAR } & توان fle & 1 \\
\hline & نسبت پِاريزاسيونه & 1 \\
\hline & همبستكى يلاريزاسيونها 19 & r \\
\hline تمام ويزگى ها & & 94 \\
\hline
\end{tabular}

${ }^{1}$ Scattering Matrix

${ }^{2}$ Coherency matrix elements

${ }^{3}$ Covariance matrix elements

${ }^{4}$ Krogager

${ }^{5}$ Huynen

${ }^{6}$ Barnes

${ }^{7}$ Cloude

${ }^{8}$ Holm

${ }^{9}$ Holm

${ }^{10}$ Freeman-Durden

${ }^{11}$ Yamaguchi

12 Touzi

${ }^{13}$ Cloude-Pottier

${ }^{14}$ SPAN

${ }^{15}$ Fractional Polarization

${ }^{16}$ Correlation Coefficients 


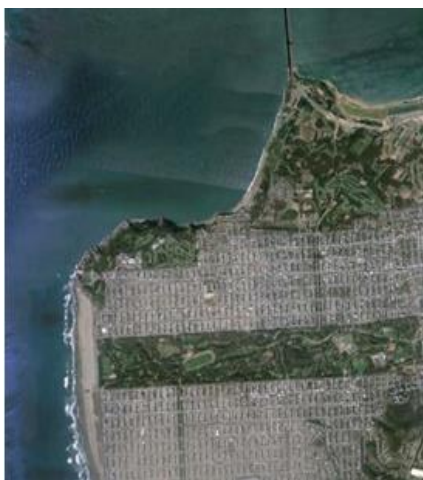

(ب

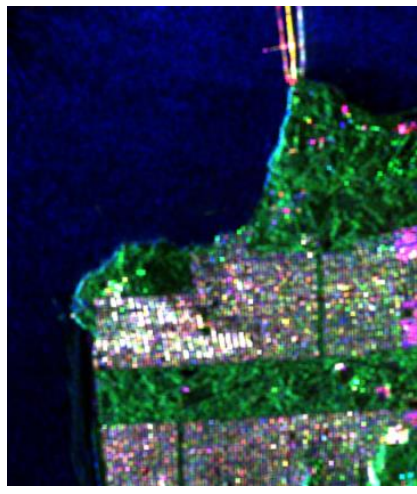

الف)

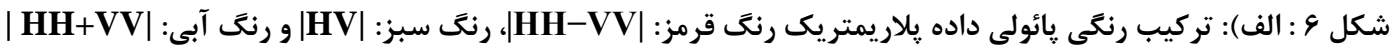
استب): تصوير كوَّل ارث از منطقه.

1) معيار كلى از عملكرد الكوريتم در طبقهبندى ارنها نشان مى دهد.

ه-1- نتــايج روش پييشـــنهادى در برابــر ســـاير روش هاى دستهجمعى SVM

در آزمايشهاى مرحله اول بيشتر هدف صحت سنجى و

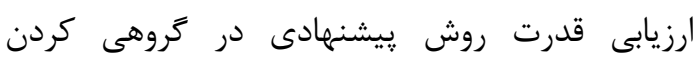
طبقهبندى كننده SVM در برابر ساير روشهاى كروهىسازى موجود در تحقيقات اخير است. بنابراين

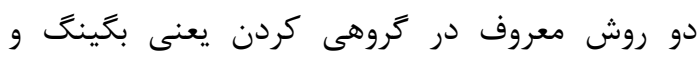

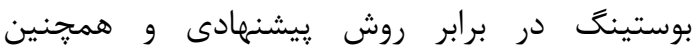

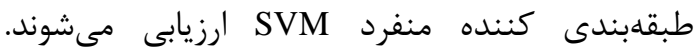
روش بحينَ در دو حالت دست كارى بر روى دادههاى آموزشى و ويزگى بهاى ورودى نشان دادهشده است.

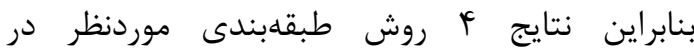

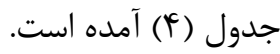
جدول (b) و جدول (\&) نتايج ارزيابى دقت روشهاى جدول (أ) را براى هر دو مجموعه داده نشان مى دهدي. مطابق نتايج دقت كلى تمام روشهاى كروهى بيشتر از

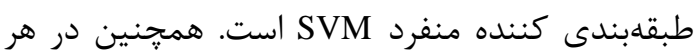

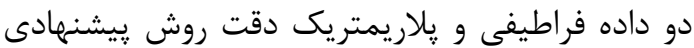
از ساير روشهاى جمعى بالاتر است.
ه- يِيادهسازى و تحليل نتايج

روند آزمايشها و تحليل آنها بهمنظور ارزيابى روش

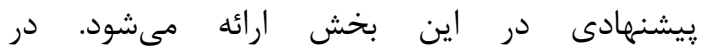
ارزيابى نتايج سه ديدكاه وجود دارد: (1) ارزيابى روش إنى ييشنهادى در برابر ساير روشهاى دستهجمعى كه از SVM بهعنوان طبقهبندى كننده يايه استفاده مىشود.

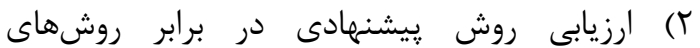

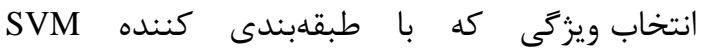
استفاده مىشوند. r) مقايسه نتايج طبقهبندى روش ييشنهادى در برابر ساير روشهاى طبقهبندى קايه (بيشترين شباهت/ ويشارت) و قدرتمند (شبكه عصبى و جنغل تصادفى). نتايج طبقهبندى با نمونههاى آموزشى و آزمايشى

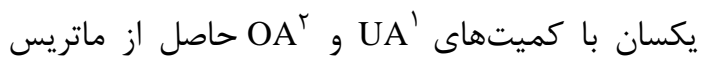

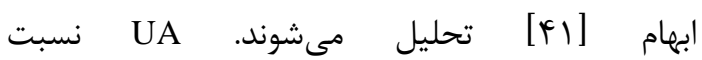
ييكسلهاى درست شناختهشده در كلاس مربوطه به كل پيكسلهاى مرجع در آن كلاس است. مقدار بالاى هA

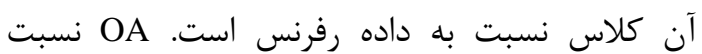
مجموع קֶيكسلهاى درست شناسايىشده به مجموع كل پيكسلهاى رفرنس در تمام كلاسها است. OA

${ }^{1}$ User Accuracy

${ }^{2}$ Overal Accuracy 
جدول f : مشخصات روشهاى مورد بررسى در دسته آزمايشهاى اول

\begin{tabular}{|c|c|c|}
\hline 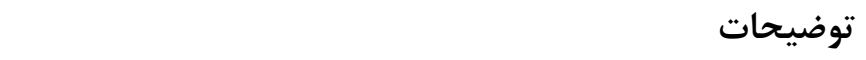 & 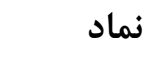 & 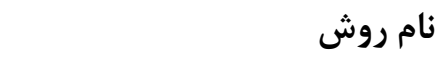 \\
\hline طبقهبندى كننده منفرد به روش ماشين بردار يشتيبان & SVM & ماشين بردار رشتيبان' \\
\hline روش گروهى SVM با دست كارى فضاى ويزگى ورودى & BFSVM & بخينگ-ويزگى \\
\hline روش گروهى SVM با دست كارى نمونههاى آموزشى & BTSVM & SVM \\
\hline روش گروهى SVM با تقويت در روند آموزش & BSVM & بوستينگ ماشين بردار يشتيبان ب \\
\hline 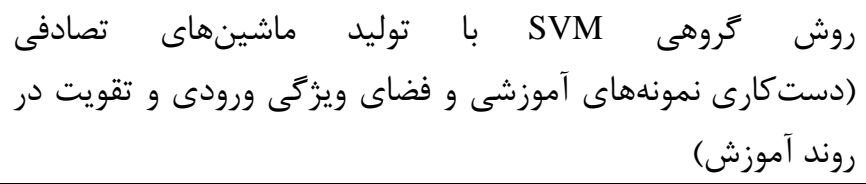 & SVRMs & 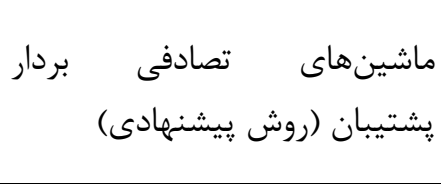 \\
\hline
\end{tabular}

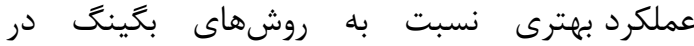

دادههاى آموزشى، بحينَ در فضاى ويزَّى ورودى

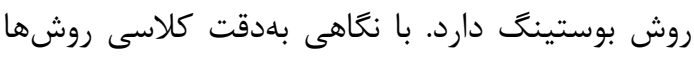
عملكرد مطلوب روش ييشنهادى در بيشتر كلاسهاى براي موردبررسى مشخص مىشود. از بين 19 كلاس 11

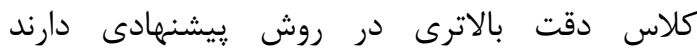

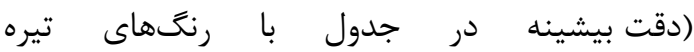
مشخصشده است) و در ه كلاس ديخر نيز بسيار نزديك به عملكرد بيشينه در ساير روشها هستند.

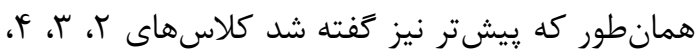

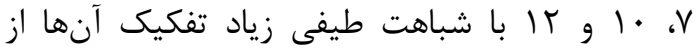
اهميت بالايى برخوردار است روش يُشيشنهادى بهجز

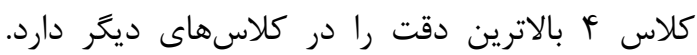
شكل(V-الف) نقشهى خروجى SVM و شكل(V-ب) نقشهى خروجى روش پيشنهادى را نشان مىدهند.

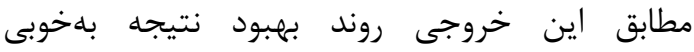

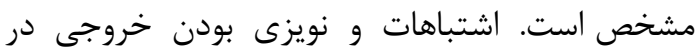
روش ييشنهادى بهطور قابل توجهى كاهش يافته است.
در تصوير فراطيفى دقت كلى روش پِيشنهادى در

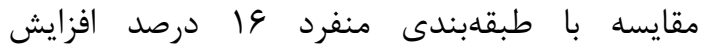

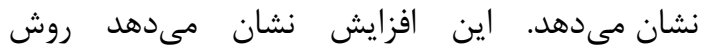
بيشنهادى در حل مشكل فضاى بزرى ويزگى موفق إنى

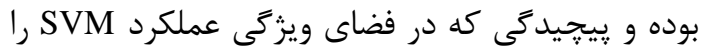

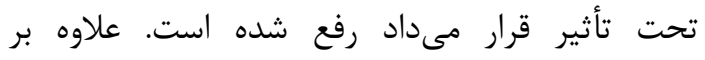
اين روش بيشنهادى در مقايسه با سه روش گروهي

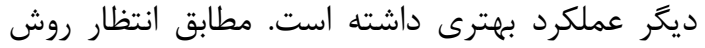
بيشنهادى كه تلفيقى از سه روش گروهي دئى ديخر است

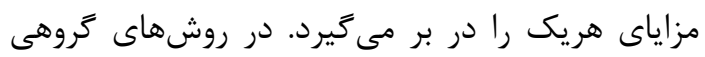
صحت، تنوع و استقلال طبقلهبندى كنندههاى پايه ركن مهمى است. در روش پيشنههادى با بهكار گيرى همزمان

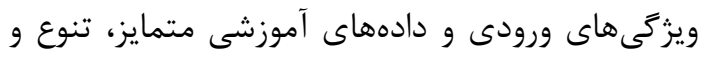

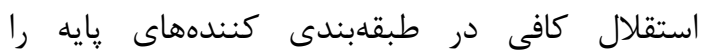
تضمين مى كند. همجنين استفاده از روش بوستينح در روند آموزش SVM بلهصورت تدريجى صحت

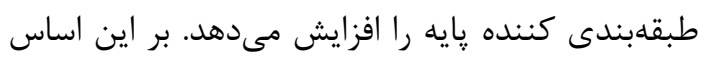
در تصوير فراطيفى روش ييشنهادى به ترتيب حدود V، ه و أ درصد در دقت كلى طبقهبندى (OA)

\footnotetext{
${ }^{1}$ Support Vector Machine

${ }^{2}$ Bagging-Features-SVM

${ }^{3}$ Bagging-Training-SVM

${ }^{4}$ Boosting Support Vector Machines
} 
جدول ه: دقت كلاسى (UA) و دقت كلى (OA) طبقدبندى داده فراطيفى

\begin{tabular}{|c|c|c|c|c|c|c|c|c|c|c|c|c|c|c|c|c|c|}
\hline 19 & 10 & if & Ir & ir & 11 & 1. & 9 & $\Lambda$ & V & 9 & $\Delta$ & $f$ & $r$ & $r$ & 1 & \}: & 3 \\
\hline $9 \% / \Delta$ & $9 N / 1$ & $\Lambda T / T$ & $94 / 9$ & $99 / 9$ & $\Delta 9 / \pi$ & VNハ & $1 \ldots$ & १९/^ & 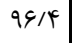 & $91 / 0$ & 19/ & $\Delta F / q$ & $9 r / 9$ & VI/ & $\wedge \uparrow / \Lambda$ & UA & \multirow{4}{*}{ BTSVMs } \\
\hline \multicolumn{16}{|c|}{ VT/QT } & $\mathrm{OA}$ & \\
\hline $9 \Delta / 1$ & VT/V & $\Lambda V / \pi$ & 9819 & $9 N / 1$ & $V \& / 9$ & $1 F / \Delta$ & $1 \cdots$ & १९/ & $9 \pi / 1$ & $9 T / 0$ & $9 \pi / 4$ & $v^{k}$ & $V T / \Delta$ & $\Lambda \mu / \uparrow$ & $\Lambda \Lambda / V$ & UA & \\
\hline \multicolumn{16}{|c|}{ NT/MI } & $\mathrm{OA}$ & \\
\hline $94 / 1$ & $V I / \wedge$ & 19/9 & $9 \% / 6$ & $V \Psi / T$ & $\Lambda \mu / 1$ & $\Lambda V / \mu$ & $\Lambda \notin / V$ & $9 Y / T$ & $9 \cdot 11$ & $94 / 9$ & $9 \pi / T$ & $V r / 9$ & $V \backslash / 1$ & $\Lambda \Delta / \Gamma$ & $\Lambda \Delta / 1$ & UA & \multirow{2}{*}{ BFSVMs } \\
\hline \multicolumn{16}{|c|}{$\Lambda \& / \Delta$} & $\mathrm{OA}$ & \\
\hline $9 \Delta / V$ & $V$ & 9. & $94 / 1$ & $\Lambda V / \Delta$ & $11 / \pi$ & $\Lambda N / \Delta$ & 1. & $9 \wedge / \%$ & 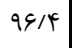 & $9 \Upsilon / \wedge$ & q & $V \varepsilon / \pi$ & $V \varepsilon / 9$ & v৭/^ & $9 \Delta / 9$ & UA & \multirow{2}{*}{ BSSVMs } \\
\hline \multicolumn{16}{|c|}{$\Lambda \Delta / T \Delta$} & $\mathrm{OA}$ & \\
\hline $94 / 9$ & $V \wedge / Y^{F}$ & $9 T / \pi$ & $9 \xi / 4$ & $19 / 7$ & 19/9 & $91 / 0$ & $1 \cdots$ & $9 \wedge / 1$ & $9 V$ & $9 \Delta / 9$ & $9 \pi / 4$ & $V Q / 9$ & $V V / 9$ & $19 / \pi$ & $9 \Delta / 1$ & UA & \multirow{2}{*}{ SVRMs } \\
\hline \multicolumn{16}{|c|}{$19 / V^{k}$} & OA & \\
\hline
\end{tabular}
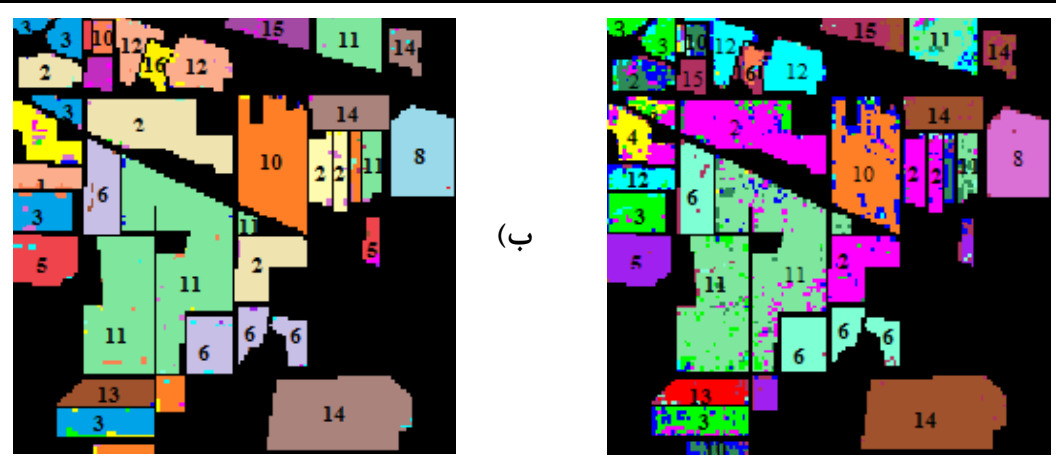

الف)

شكل V : خروجى طبقدبندى داده فراطيفى؛ الف) طبقدبندى منفرد SVM ب) روش يِيشنهادى (SVRMs)

مشهود است. بهجز كلاس جاده در ساير كلاسها

بهترين نتايج مربوط به روش پيشنهرادى است. به دليل

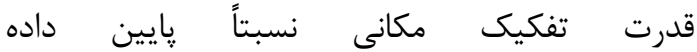

تفكيك كلاسهاى جاده و ساختمان در يك فضاى

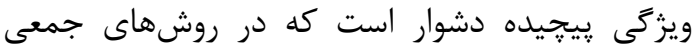

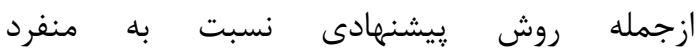

بهبود قابلتوجهى داشته است.

جدول 9 : دقت كلاسى (UA) و دقت كلى (OA) طبقهبندى داده يلاريمتريك

\begin{tabular}{|c|c|c|c|c|c|c|}
\hline يوشش كياهى & آب & درخت & ساختمان & جاده & كميت & روش \\
\hline $1 \cdots$ & $9 \wedge / \vee \wedge$ & VV/GT & V9/D & $91 / .1$ & UA & \multirow{2}{*}{ SVM } \\
\hline \multicolumn{5}{|c|}{$\Lambda \vee / \% q$} & $\mathrm{OA}$ & \\
\hline $1 \cdots$ & q৭/VA & Vq/IT & $\Lambda \mu / q \Lambda$ & $V Y / \cdot 1$ & $\overline{\mathrm{UA}}$ & \multirow{2}{*}{ BTSVMs } \\
\hline \multicolumn{5}{|c|}{$19 / 79$} & $\mathrm{OA}$ & \\
\hline $1 \cdots$ & $1 \cdots$ & 19 & $11 / .9$ & Vर/9I & $\overline{\mathrm{UA}}$ & \multirow{2}{*}{ BFSVMs } \\
\hline \multicolumn{5}{|c|}{$91 / . r$} & $\mathrm{OA}$ & \\
\hline $1 \cdots$ & $1 \cdots$ & $19 / 91$ & $91 / \Delta r$ & AY/FT & UA & \multirow{2}{*}{ BSSVMs } \\
\hline \multicolumn{5}{|c|}{$q 4 / q 4$} & $\mathrm{OA}$ & \\
\hline
\end{tabular}




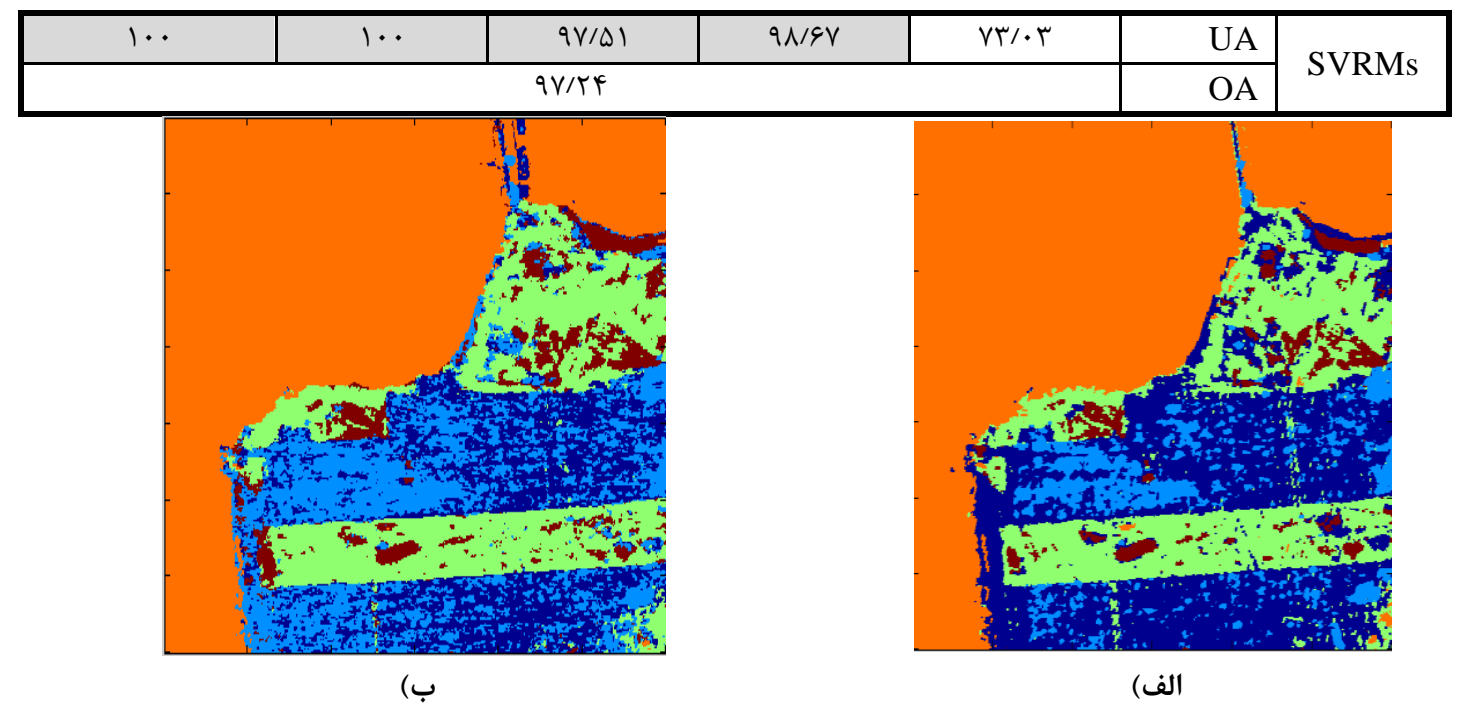

شكل ^ : خروجى طبقهبندى داده پِاريمتريك؛ الف): طبقهبندى منفرد SVM؛ ب): روش پِيشنهادى (SVRMs)

موجود مىباشد. الكوريته زنتيك دو عملگر شامل

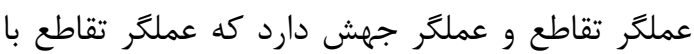

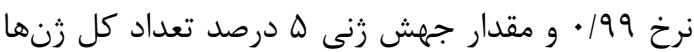
انتخاب شد. شرط توقف نيز تغييرات كمتر از 1 •• درصد در دقت كلى قرار داده شد اما حداكثر تعداد

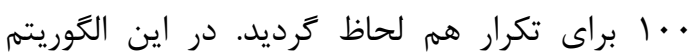
دقت كلى طبقهبندى حاصل از دادهاى آزمايشى

بهعنوان تابع هزينه استفادهشده است. (شكل (9))

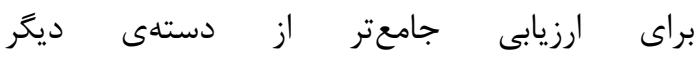

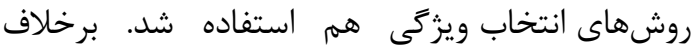
روش رنتيك در اين دسته تنها با معيارهايى

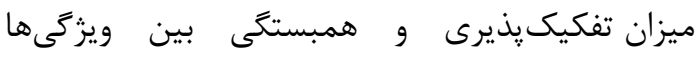

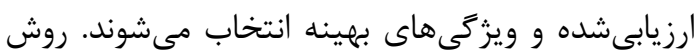
CFS براى مقايسه در اين مقاله انتخاب شدند.

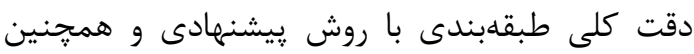
طبقهبندى كننده SVM همراه با روشهاى انتخاب

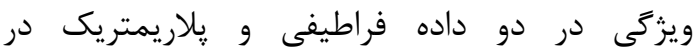
جدول (V) آمده است. همانطور كه نتايج نشان مى دهدي در مقايسه با روشهاى انتخاب ويزگى هم موفقيت

\footnotetext{
${ }^{2}$ Correlation-based Feature Selection

${ }^{3}$ Chi-square
}

\section{ه-Y- - نتايج روش ييشنهادى در برابــر روشهـاى} طبقهبندى همراه با انتخاب ويزَّى اين بخش به مقايسه و تحليل نتايج روش ييشنهادى در برابر استفاده از روشهاى انتخاب ويز كى اختى اختصاص دارد. همانطور كه در مقدمه كفته شد براى مقابله با ابعاد

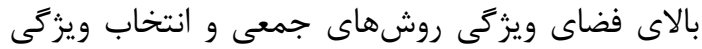

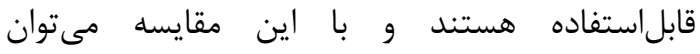
روش ريشنهادى را از ديدگاه موفقيت در محاسبات ابعاد فضاى ويزگى بالا ارزيابى نمود. به اين منظور از بين روشهاى انتخاب ويزگگى مختلف يكى از بهترين روشها در تحقيقات اخير [FF الكوريتم زنتيك ' براى استفاده انتخاب شد. در الخوريتم زنتيك براى انتخاب ويزگى يكى جمعيت اوليه از

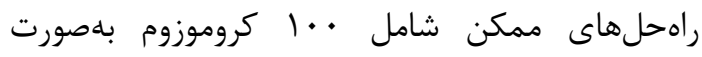
تصادفى ايجاد شد. هر كروموزوم از تعدادى زن زن تشكيلشده است، تعداد زنها معادل با تعداد ويزگى هاى ورودى مىباشد كه هر زن در هر كروموزوم معادل با يكى از ويزگى هاى تصوير است. إنى معادل بودن و · معادل نبودن آن ويزگى در راهحل (كروموزوم)

${ }^{1}$ Genetic Algorithm 
بين روشهاى انتخاب ويزگى (زُنتيك) برترى دارد كه

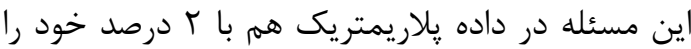

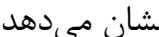

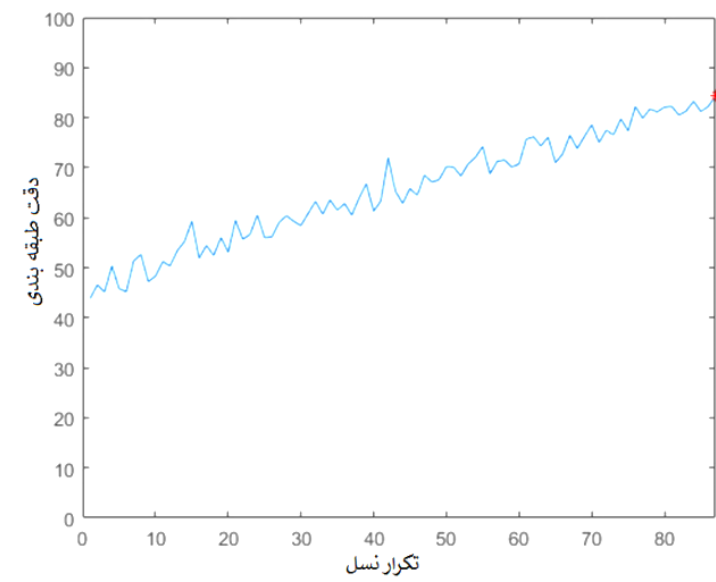

(ب)
روش پيشنههادى تصديق مىشود. بهعبارتديخر روش

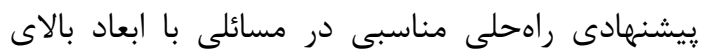

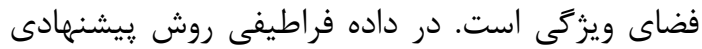
حدود له درصد نسبت به بهترين نتيجه در

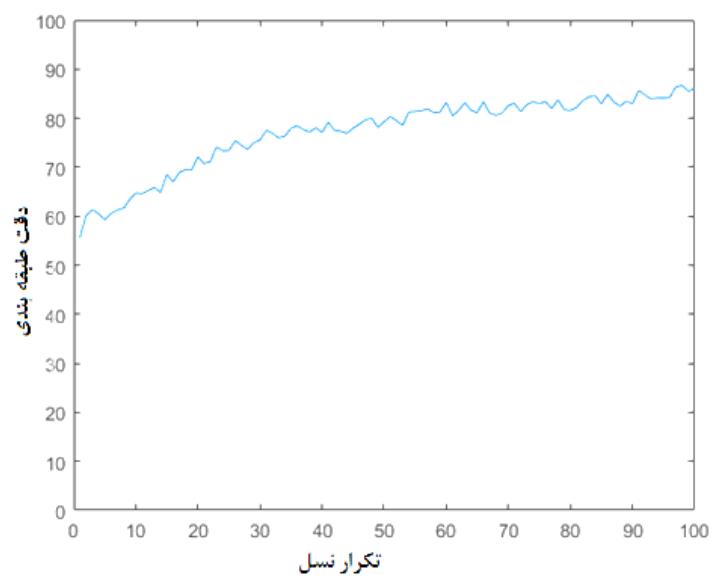

الف)

شكل 9 : نمودار تغييرات دقت كلى طبقدبندى در تكرار نسلهاى مختلف روش بهينهسازى زنتيك الف): بهترين دقت؛ ب): دقت

$$
\text { ميانغين در هر نسل مخلف }
$$

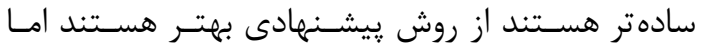

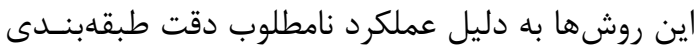

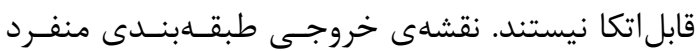

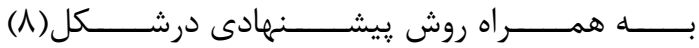
نشان دادهشه است. تفكيك دو كلاس سـاختمان و راه

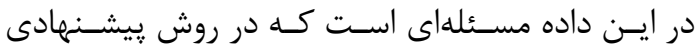
بهبود يافته و بلهور محسوسى در نقشه نيز اين موضوع داده

مشخص است.
يكى ديكر از جنبههاى اين مقايسه هزينهى محاسـباتى

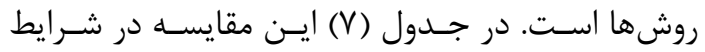

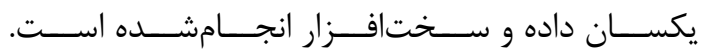
روش پِيشنهادى اگرجه هزينه محاسباتى بالاترى نسبت

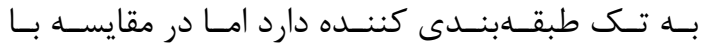
روش زنتيك كه ماهيتى تكـرارى در بهينـهسـازى دارد

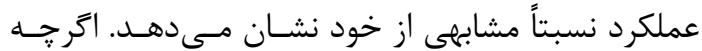

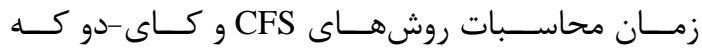

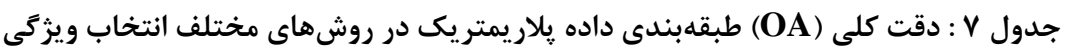

\begin{tabular}{|c|c|c|c|c|c|}
\hline (ثانيه) $\quad$ زمان $\quad$ محاسباتى & دقت كلى & زمان $\quad$ زماسيه) & دقت كلى & ورئى انتخاب & روشق \\
\hline IFTA & $q V / T F$ & . & ᄉq/vF & & SVRMs \\
\hline $1 \mu \cdot \Delta$ & $9 \Delta / V \mu$ & TYYT & $\Lambda F / T V$ & GA & SVM \\
\hline 653 & $9.1 \cdot 1$ & $195 \mid$ & $\mathrm{VV} / \mathrm{A \Lambda}$ & CFS & SVM \\
\hline$V+1$ & 19/9V & 119. & V৭/v V & كاى-دو & SVM \\
\hline
\end{tabular}




\section{9- نتيجه}

در اين مقاله بهمنظور بهبود عملكرد طبقهبندى كننده در فضاى ويزگى با ابعاد بالا روشى دستهجمعى SVM

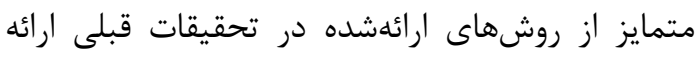
شد. روشهاى دستهجمعى از طبقهبندى كنندههاى يايهاى تشكيلشدهاند كه درنهايت تجميع آنها

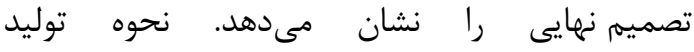
اين طبقهبندى كنندههاى پايه و تجميع آنها از نكات بارز در دقت نهايى روشها و وجه تمايز آنها است. روشهاى دستهجمعى همسان از طبقابندى كنندههاى

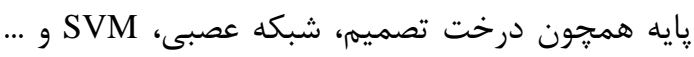

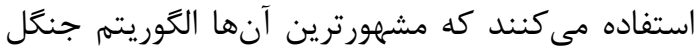
تصادفى كه با استفاده از درختهاى تصميم متنوع و

مستقل همراه با خاصيت تصادفى بهره مىبرد است. روش بيشنهادى اين مقاله داراى سه وجه تمايز مهمم در

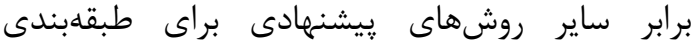
جندكانه با SVM است. اول در توليد خود راهاندازها و و براي طبقهبندى كنندههاى پايه است كه با در نظر كرفتن

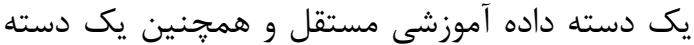
ويزگى ورودى مستقل از ساير خود راهاندازها تنوع و استقلال كافى را در بين طبقلهبندى كنندههاى إيايه ايجاد مى كند. دوم در آموزش طبقهبندى كنيندههاى

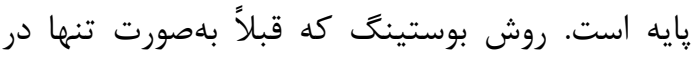

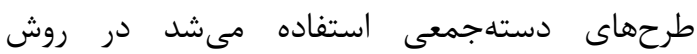
ريشنهادى در كنار روش بخينگ به كار كرفته شد كه خود موجب بهببود تعيين بهترين حاشيه در آموزش بكرين يادكيرنده SVM و همجنين توليد بيشتر طبقهبندى كنندهاى קِايه مىشود. سوم استفاده از يك طرح تجميع غيرخطى و دقيقتر نسبت به طرحهايى همجون

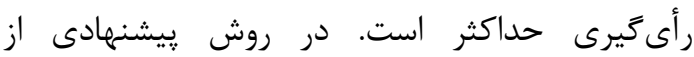
تلفيق كننده بر مبناى SVM استفادهشده است كه سطوح احتمال حاصل از طبقهبندى كنندههاى بايه بهنوان ويزگى هاى ورودى آن مىباشند. ه-r - نتــايج روش ييشـــههادى در برابــر ســاير روشهاى طبقهبندى

صـحت روش ييشــنهادى در برابــر روشهــاى مختلـف

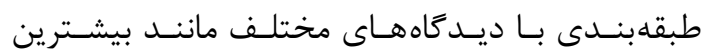
شباهت (يارامتريك)، شبكه مصنوعى عصـبى و جنَــل تصادفى (غير קارامتريك) سنجيده مىشـود جـدول (^)

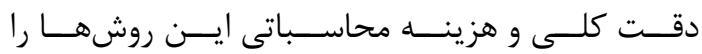

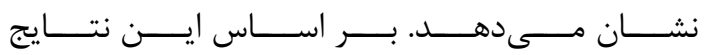
صحت روش ييشنهادى در داده فراطيفى و يلاريمتريك

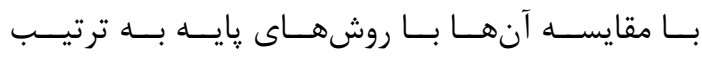

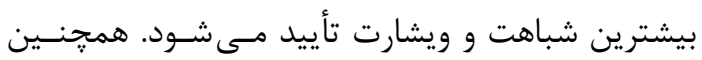
مطابق نتايج دقت روش ييشنهادى در برابـر روشهـاي جنكل تصادفى و شبكه عصـبى مشهـود اسـت. يكسى از

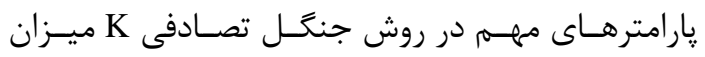

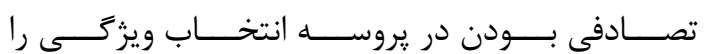
كنترل مى كند. وقتى K برابر تعداد كل ويزگَىها باشـد، درخت تصميم ساخته شده مشابه درخت تصميم قطعى

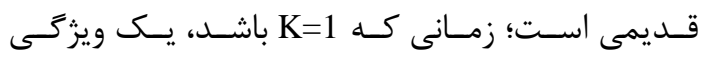

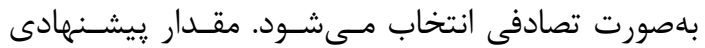

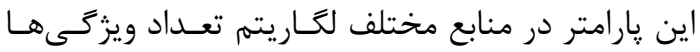

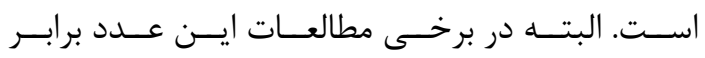

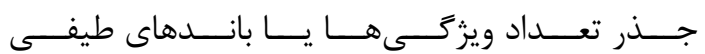
در نظر كرفتهشده است. در اين تحقيق مقـدار لكَاريتم

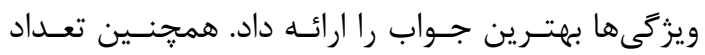

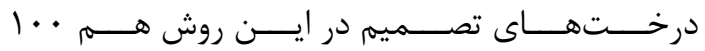

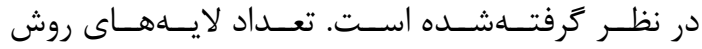
شبكه عصبى هم ץ در نظر كرفته شد كه بهترين پاسـخ در نتايج طبقهبندى اين روش را ارائهه داد. تـابع بهينــهـ كننده مورد استفاده در اين روش تابع سيخمويد' است.

1 Sigmoid 
جدول ^ : دقت كلى (OA) طبقهبندى در روشهاى مختلف پايه و قدرتمند

\begin{tabular}{|c|c|c|c|c|}
\hline \multicolumn{2}{|c|}{ داده يلاريمتريك } & \multicolumn{2}{|c|}{ داده فراطيفى } & \multirow{2}{*}{ روش طبقهبندى } \\
\hline زمان محاسباتى (ثانيه) & دقت كلى & زمان محاسباتى (ثانيه) & دقت كلى & \\
\hline IFTA & qV/TF & (9 & १९/vi & SVRMs \\
\hline 91. & $94 / 9 V$ & $1 \wedge \Delta F$ & 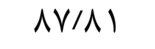 & Random Forest \\
\hline 997 & MN/DT & $|V 9|$ & טr/r & Neural Network \\
\hline 901 & 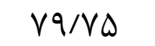 & 19D & $9 V / M I$ & ML/Wishart \\
\hline
\end{tabular}

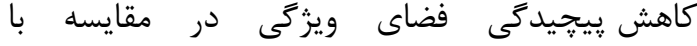

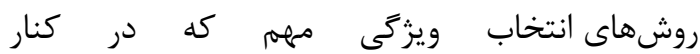
طبقهبندى كننده SVM استفاده مىشوند مقايسه شد.

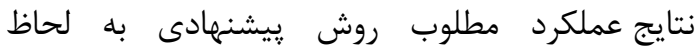
دقت كلى در طبقهبندى و هزينه محاسباتى را نسبت

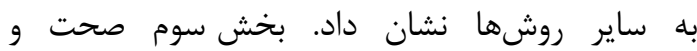
دقت روش طبقهبندى زيشنهادى در برابر روشهاى روني طبقهبندى ديكر همجون جنگل تصادفى، شبكه عصبى و بيشترين شباهت/ ويشارت ارزيابى شد كه نه نتايج عملكرد مناسب روش ييشنهادى را تصديق مى كرد.

[1] D. Landgrebe, "Hyperspectral image data analysis," Signal Processing Magazine, IEEE, Vol. 19, pp. 17-28, 2002.

[2] M. T. Eismann, "Hyperspectral remote sensing," University of Maryland, 2012.

[3] S. Vishnu, R. R. Nidamanuri, and R. Bremananth, "Spectral material mapping using hyperspectral imagery: a review of spectral matching and library search methods," Geocarto International, Vol. 28, pp. 171-190, 2013.

[4] J.-S. Lee and E. Pottier, Polarimetric radar imaging: from basics to applications, CRC press, 2009.

[5] M. Jafari, Y. Maghsoudi, M. J. V. Zoej, "A New Method for Land Cover Characterization and Classification of Polarimetric SAR Data Using Polarimetric Signatures", Selected Topics in Applied
نتايج روش ييشنهادى بر روى دو داده با فضاى ويزگى

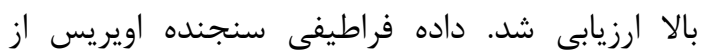

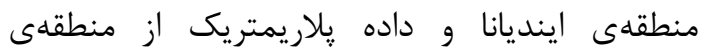

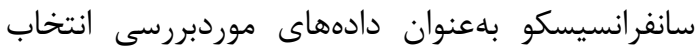
شدند. آزمايشها در سه بخش طراحى و تحليل شدند. در بخش اول نتايج روش بيشنههادى در برابر ساير روشهاى جمعى با SVM مقايسه شد. نتايج نشان داد در دقت كلى و در اغلب كلاسها مخصوصاً كلاسهايى بـ

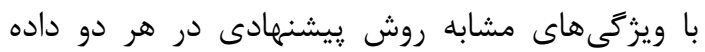

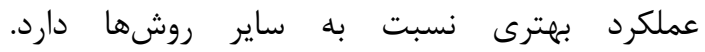

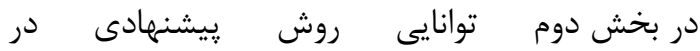

$$
\text { مراجع }
$$

Earth Observations and Remote Sensing, IEEE Journal of, Vol . 8, pp. 3595-3607, 2015.

[6] Z. Qi, A. G.-O. Yeh, X. Li, and Z. Lin, "A novel algorithm for land use and land cover classification using RADARSAT-2 polarimetric SAR data," Remote Sensing of Environment, Vol. 118, pp. 21-39, 2012.

[7] M. Jafari, Y. Maghsoudi, and M. J. V. Zoej, "Analyzing polarimetric signatures for different features in polarimetric SAR data," in Geoscience and Remote Sensing Symposium (IGARSS), 2014 IEEE International, 2014, pp. 2782-2785.

[8] M. Jafari, M. Valadanzoej, and Y. Maghsoudi, "Knowledge-based Classification of Polarimetric SAR data using Support Vector Machine-Decision Tree (SVM-DT)," Journal of Geomatics 
Science and Technology, Vol. 5, pp. 93-108, 2015.

[9] M. Jafari, Y. Maghsoudi, and M. Zoej, "A New Component Scattering Model Using Polarimetric Signatures Based Pattern Recognition on Polarimetric SAR Data," Journal of the Indian Society of Remote Sensing, Vol.8, pp. 1-10, 2016.

[10] G. P. Hughes, "On the mean accuracy of statistical pattern recognizers," Information Theory, IEEE Transactions on, Vol. 14, pp. 55-63, 1968.

[11]D. A. Landgrebe, Signal theory methods in multispectral remote sensing vol. 29: John Wiley \& Sons, 2005.

[12] S. Kumar, "Modular learning through output space decomposition," UNIVERSITY OF TEXAS AT AUSTIN, 2000.

[13] M. Fauvel, J. A. Benediktsson, J. Chanussot, and J. R. Sveinsson, "Spectral and spatial classification of hyperspectral data using SVMs and morphological profiles," Geoscience and Remote Sensing, IEEE Transactions on, Vol. 46, pp. 3804-3814, 2008.

[14] J. Gualtieri and S. Chettri, "Support vector machines for classification of hyperspectral data," in Geoscience and Remote Sensing Symposium, 2000. Proceedings. IGARSS 2000, pp. 813-815.

[15] M. Pal and P. M. Mather, "Assessment of the effectiveness of support vector machines for hyperspectral data," Future Generation Computer Systems, Vol. 20, pp. 1215-1225, 2004.

[16] G. Camps-Valls and L. Bruzzone, "Kernelbased methods for hyperspectral image classification," Geoscience and Remote Sensing, IEEE Transactions on, Vol. 43, pp. 1351-1362, 2005.

[17]G. Mercier and M. Lennon, "Support vector machines for hyperspectral image classification with spectral-based kernels," in Geoscience and Remote Sensing Symposium, IGARSS2003, 2003, pp. 288290.
[18] Y. Huang, J. Cai, L. Ji, and Y. Li, "Classifying G-protein coupled receptors with bagging classification tree," Computational biology and chemistry, Vol. 28, pp. 275-280, 2004.

[19] A. Liaw and M. Wiener, "Classification and regression by randomForest," $\mathrm{R}$ news, Vol. 2, pp. 18-22, 2002.

[20]L. K. Hansen and P. Salamon, "Neural network ensembles," IEEE Transactions on Pattern Analysis \& Machine Intelligence, pp. 993-1001, 1990.

[21]D. B. Skalak, "Prototype selection for composite nearest neighbor classifiers," University of Massachusetts Amherst, 1997.

[22] S. D. Bay, "Nearest neighbor classification from multiple feature subsets," Intelligent data analysis, Vol. 3, pp. 191-209, 1999.

[23]T. G. Dietterich, "Ensemble methods in machine learning," in Multiple classifier systems, ed: Springer, 2000, pp. 1-15.

[24]D. Bahler and L. Navarro, "Combining heterogeneous sets of classifiers: Theoretical and experimental comparison of methods," presented at the 17th National Conference on Artificial Intelligence (AAAI 2000), Workshop on New Research Problems for Machine Learning, 2000.

[25] G. Valentini and F. Masulli, "Ensembles of learning machines," in Neural Nets, ed: Springer, 2002, pp. 3-20.

[26] D. Opitz and R. Maclin, "Popular ensemble methods: An empirical study," Journal of Artificial Intelligence Research, pp. 169198, 1999.

[27] G. Giacinto and F. Roli, "An approach to the automatic design of multiple classifier systems," Pattern recognition letters, Vol. 22, pp. 25-33, 2001.

[28] J. M. P. d. Gama, "Combining classification algorithms," University of Porto, 1999.

[29] C. Cortes and V. Vapnik, "Support-vector networks," Machine learning, Vol. 20, pp. 273-297, 1995.

[30] C. J. Burges, "A tutorial on support vector 
machines for pattern recognition," Data mining and knowledge discovery, Vol. 2, pp. 121-167, 1998.

[31] V. N. Vapnik and V. Vapnik, Statistical learning theory vol. 1: Wiley New York, 1998.

[32]H.-C. Kim, S. Pang, H.-M. Je, D. Kim, and S.-Y. Bang, "Support vector machine ensemble with bagging," in Pattern recognition with support vector machines, ed: Springer, 2002, pp. 397-408.

[33]Z.-H. Zhou, Ensemble methods: foundations and algorithms: CRC Press, 2012.

[34] Y. Freund and R. E. Schapire, "Experiments with a new boosting algorithm," in ICML, 1996, pp. 148-156.

[35]L. Breiman, "Bagging predictors," Machine learning, Vol. 24, pp. 123-140, 1996

[36]B. X. Wang and N. Japkowicz, "Boosting support vector machines for imbalanced data sets," Knowledge and Information Systems, Vol. 25, pp. 1-20, 2010.

[37] Universidad-del-Pais-Vasco. Hyperspectral Remote Sensing Scenes [Online]. Available: http://www.ehu.es/ccwintco/index.php?title= Hyperspectral_Remote_Sensing_Scenes

[38] Purdue-Research-Foundation. Hyperspectral Images by MultiSpec $($ [Online]. Available: https://engineering.purdue.edu/ biehl/Multi Spec/hyperspectral.html
[39] B. Mojaradi, H. Abrishami-Moghaddam, M. J. V. Zoej, and R. P. Duin, "Dimensionality reduction of hyperspectral data via spectral feature extraction," Geoscience and Remote Sensing, IEEE Transactions on, Vol. 47, pp. 2091-2105, 2009.

[40]F. van der Meero and W. Bakker, "Cross correlogram spectral matching: application to surface mineralogical mapping by using AVIRIS data from Cuprite, Nevada," Remote Sensing of Environment, Vol. 61, pp. 371-382, 1997.

[41] A. Hay, "The derivation of global estimates from a confusion matrix," International Journal of Remote Sensing, Vol. 9, pp. 1395-1398, 1988.

[42]J. Yang and V. Honavar, "Feature subset selection using a genetic algorithm," in Feature extraction, construction and selection, ed: Springer, 1998, pp. 117-136.

[43]R. Leardi, "Application of genetic algorithm-PLS for feature selection in spectral data sets," Journal of Chemometrics, Vol. 14, pp. 643-655, 2000.

[44] S. Oreski and G. Oreski, "Genetic algorithmbased heuristic for feature selection in credit risk assessment," Expert systems with applications, Vol. 41, pp. 2052-2064, 2014. 


\title{
Support Vector Random Machines (SVRMs), A Optimum Multiclassifier for Big Data
}

\author{
Mohsen Jafari ${ }^{*}{ }^{1}$, Mehdi Akhoundzadeh ${ }^{2}$ \\ 1- PhD. Student, Remote Sensing Department, Faculty of Surveying and Geoinformation Engineering, College of Engineering, University of Tehran \\ 2- Assisstant Professor, Remote Sensing Department, Faculty of Surveying and Geoinformation Engineering, College of Engineering, University of \\ Tehran
}

\begin{abstract}
Although, the distinction between the land cover classes was increased in large feature space of remote sensing images, but the low number of training data prevent this. In order to solve this problem, ensemble classification methods can be used instead of individual classifiers. In this paper, a new method for ensemble support vector machine was proposed called "Support Vector Random Machines (SVRMs)". In proposed method, bootstrap was produced using modification of training data and feature space. Simultaneous boosting SVM was used for basic classifiers. Then, classification map was resulted using SVM fusion of basic classifier. Hyperspectral and Polarimetric SAR data was chosen for evaluation performance of the SVRMs. Experiments were evaluated from three different points of view: First, evaluation against other ensemble SVM methods; second, evaluation against various feature selection methods in classification and third, evaluation against the various basic and new classification methods. As the results, proposed method is $16 \%$ better than the individual SVM classifier in hyperspectral data and this is $10 \%$ in PolSAR data. Also, the classification results of SVRMs in various classes compared to other SVM ensemble method were improved. The results reported from the proposed method compared to the other feature selection method (Genetic Algorithm) has the effectual performance in classification. The results show that the proposed method presents a better performance compared to the basic classification methods (maximum likelihood and wishart) and advanced classification (random forest and neural network).
\end{abstract}

Key words: Support Vector Machine (SVM), Ensemble method, Feature space, Bootstarp, Aggregation.

Correspondence Address. Remote Sensing Department, Faculty of Surveying and Geoinformation Engineering, College of Engineering, University of Tehran, Iran.

Tel: +989366153637

Email: jafarim@ut.ac.ir 